\title{
CAPITAL SENTENCING: THE EFFECT OF ADDING AGGRAVATORS TO DEATH PENALTY STATUTES IN PENNSYLVANIA
}

\author{
Sandra Schultz Newman, ${ }^{*}$ Eric Rayz, ${ }^{* *}$ and Scott Eric Friedman ${ }^{* * *}$
}

\section{INTRODUCTION}

The birthplace of the American republic - the Commonwealth of Pennsylvania - has historically been at the forefront of the capital punishment legislation in the United States. It was the first colony in the Union to abolish the death penalty for all crimes with the exception of murder. It was the first to set forth a statutory distinction between different degrees of criminal homicide, confining imposition of capital punishment to the most chilling form of this crime - "willful, deliberate, and premeditated killing." With this storied history in mind, we have undertaken the task of examining the current state of the death penalty in the Commonwealth. Hence, in Part II of this Article, we set forth a detailed history of the capital sentencing scheme in Pennsylvania. Part III undertakes a statistical study of the imposition of the death penalty in the Commonwealth from 1978 until 1997. In Part IV, we conclude by summing up our general observations.

\section{History of the Death Penalty in Pennsylvania}

The Charter for the colony of Pennsylvania, granted by King Charles II to William Penn in 1681, established that the laws of England respecting

\footnotetext{
* Justice of the Pennsylvania Supreme Court-1996 to present; Judge of the Pennsylvania Commonwealth Court-1994 to 1996. Justice Newman received her J.D. from Villanova Law School, her M.A. from Temple University, and her B.S. from Drexel University.

** Eric Rayz serves as a law clerk to Justice Newman. He received his J.D. and his B.A. from Temple University.

*** Scott Friedman serves as a law clerk to Justice Newman. He received his J.D. from Washington University School of Law in St. Louis and his B.A. from Brandeis University. The authors would like to thank many people for their contributions to this article, including those who read and commented on the manuscript. The authors would especially like to thank Robert Katz, Bret Binder, Tracy Haslett, Don Harris of the Administrative Office of Pennsylvania Courts, Jane Smith Stewart and the staff of the State Library of Pennsylvania in Harrisburg, the staff of Jenkins Law Library in Philadelphia, and the staff of the Villanova University Law Library.
} 
crimes and their punishments would continue perforce in the colony until such time as they "shall be altered by the said William Penn, his heires or assignes, and by the freemen of the said Province, their Delegates or Deputies, or the greater part of them."1 The Charter, however, did not grant to Penn unfettered authority, providing that Charles' Privy Council could reject any law adopted pursuant to the Charter. ${ }^{2}$ Specifically, the Crown directed that every five years Penn was required to transmit all laws adopted by the colony for "royal approbation or dissent." " Charles also directed that the laws promulgated by Penn should be as close to the rules of England as practicable. ${ }^{4}$

Prior to 1682, the Crown imposed the death penalty for a multitude of crimes in Great Britain; the Crown considered the following eleven offenses capital crimes in Pennsylvania at that time: (1) denial of true God; (2) willful and premeditated murder; (3) slaying a defenseless person with a sword or dagger; (4) killing by lying in wait, poisoning, or conspiracy; (5) buggery; (6) sodomy; (7) kidnapping; (8) bearing false witness to take away life; (9) treason; (10) invasion and surprise of towns and forts under government control; and (11) smiting of one's father or mother. ${ }^{5}$ Despite the clear limiting intent of the Charter, however, Penn quickly put forth "humane laws," also known as "The Great Law," which, inter alia, limited the death penalty to the crime of willful and premeditated murder. ${ }^{6}$ William Bradford, the second

1. Charter to William Penn and Laws of the Province of Pennsylvania, Passed Between THE YEARS 1682 AND 1700 at 84 (Published Under the Direction of the Secretary of the Commonwealth, 1879) [hereinafter CHARTER TO WILLIAM PENN].

2. Edwin R. Keedy, History of the Pennsylvania Statute Creating Degrees of Murder, 97 U. PA. L. REv. 759, 760 (1949). The "Privy Council" is "that part of [the British monarch's] Government which advises on the exercise of prerogative powers and certain functions assigned to [the monarch] and the Council by Act of Parliament." Privy Council Office, About the Privy Council Office, at http://www.privycouncil.org.uk/print/page2.asp (last visited Jan. 30, 2004).

3. William Bradford, An Enquiry How Far the Punishment of Death is Necessary in Pennsylvania 14 (Philadelphia, T. Dobson, 1793).

4. Id. at 14; REPORT OF THE MAJORITY AND MinORITY OF THE SELECT COMMITTEE OF THE HOUSE Relative to the Abrogation of CAPital Punishment, Majority Report at 7 (1846).

5. DuKE OF Yorke's LaWs, reprinted in CHARTER TO WILLIAM PENN, supra note 1, at 14-15; see also RePort of THE JoInt LegisLative COMMITTEE ON CAPITAL PUNISHMENT OF THE GENERAL ASSEMBLY of Pennsylvania at 3 (June 1961) [hereinafter Report of the Joint Legislative Committee on CAPITAL PUNISHMENT].

6. See Commonwealth v. Zettlemoyer, 454 A.2d 937, 968 (Pa. 1982), cert. denied, 461 U.S. 970 (1983), rehearing denied, 463 U.S. 1236 (1983); CHARTER To William PENN, supra note 1, at 144; see also Stuart Banner, The Death Penalty: An American History 6 (2002) (noting that "rape was not capital in the first codes of Massachusetts, New York, or Pennsylvania, and even manslaughter was not capital in the early Quaker colonies of Pennsylvania and West New Jersey, which for a time gave the Delaware Valley the most lenient punishments in the English world"). 


\section{Attorney General of the United States, ${ }^{7}$ later explained the truly remarkable nature of Penn's advancements:}

The natural tendency of this policy [to require royal approbation of laws passed in the colony] was to overwhelm an infant colony, thinly inhabited, with a mass of sanguinary punishments hardly endurable in an old, corrupted and populous country. But the Founder of the province was a philosopher whose elevated mind rose above the errors and prejudices of his age, like a mountain, whose summit is enlightened by the first beams of the sun .... [A]mong the first cares of his administration, was that of forming a small, concise, but complete code of criminal law, fitted to the state of his new settlement: a code which is animated by the pure spirit of philanthropy, and, where we may discover those principles of penal law, the elucidation of which had given so much celebrity to the philosophy of modern [late $18^{\text {th }}$ century] times. The punishments prescribed in it were calculated to tie up the hands of the criminal - to reform - to repair the wrongs of the injured party - and to hold up an object of terror sufficient to check a people whose manners he endeavoured to fashion by provisions interwoven in the same system. Robbery, burglary, arson, rape, the crime against nature, forgery, levying war against the Governor, conspiring his death, and other crimes, deemed so heinous in many countries, and for which so many thousands have been executed in Britain, were declared to be no longer capital. ${ }^{8}$

The first execution in the new colony occurred on March 15, 1688, when Judith Roe, a resident of Kent County in what is now the state of Delaware, 9 was publicly hanged for willful and premeditated murder, though the facts of the case, Roe's motive, and the identity of the victim are not known. ${ }^{10}$

The "humane laws" continued relatively unchecked until Penn's death in 1718. In 1709 and 1714, however, the Queen's Council ${ }^{11}$ rejected two laws

7. Bradford, born in 1755 , graduated from Princeton University in 1772, and became Attorney General of Pennsylvania in 1780. He served in that position for more than ten years until 1791, at which time he became a Justice of the Supreme Court of Pennsylvania. On January 27, 1794, President Washington appointed Bradford Attorney General of the United States, a position in which he served until his death on August 23, 1795. Walter Dellinger \& H. Jefferson Powell, The Attorney General's First Separation of Powers Opinion, 13 CONST. CoMmENT. 309, 313 (1996); Department of Justice, Biographies of the Attorneys General of the United States, at http://www.usdoj.gov/jmd//s/agbiographies.htm (last visited Jan. 30, 2004).

8. BRADFORD, supra note 3, at 14-16.

9. The Duke of York, upon Penn's arrival in 1682, granted the counties of what is now Delaware to Penn. See State of Delaware (A BriefHistory), at http://www.state.de.us/gic/facts/history/delhist.htm (last visited Jan. 30, 2004).

10. Negley K. TeEters, SCAFFold And Chair: A Compilation OF Their Use in Pennsylvania 1682-1962, at 1 (Published by the Pennsylvania Prison Society, 1963).

11. Queen Anne succeeded her brother-in-law, William of Orange, to the throne of the United Kingdom in 1702. William of Orange ruled with his wife, Mary II, until her death in 1694, and then ruled alone. William and Mary had taken the throne from Mary's father, James II, in 1689. James II had ruled from 1685, upon the death of his brother Charles II. The British Monarchy, History of the Monarchy: Kings and Queens of the United Kingdom (From 1603), at http://www.royal.gov.uk/output/Page92.asp (last visited 
passed by the Quaker Provincial Assembly that had allowed judicial officers and witnesses in criminal trials to make solemn affirmations rather than take oaths. $^{12}$ By rejecting these statutes, the Crown effectively removed any Quaker from holding judicial office or testifying in court. Upon Penn's death, the Quaker government, "alarmed with the prospect of political annihilation[,]" sought advice from the British Governor in Pennsylvania on how best to restore the right of affirmation. ${ }^{13}$ The Governor recommended that they copy the laws of the Crown, a suggestion with which they complied almost immediately. ${ }^{14}$

On May 31, 1718, the Provincial Assembly passed "An Act for the Advancement of Justice, and More Certain Administration Thereof," which provided, inter alia, that "affirmation of such persons as conscientiously refuse to take an oath, shall be accounted and deemed in the law to have the full effect of an oath, in any case whatsoever in this province." 15 As quid pro quo, by the same Act, the Provincial Assembly adopted what has been consistently described as a more sanguinary ${ }^{16}$ criminal code, which enumerated thirteen capital crimes: (1) high treason; (2) petit treason; (3) murder; (4) robbery; (5) burglary; (6) rape; (7) buggery/sodomy; (8) malicious maiming; (9) manslaughter by stabbing; (10) witchcraft; (11) arson; (12) concealing the death of a bastard child; and (13) advising the killing of a bastard child. ${ }^{17}$ Several subsequent enactments over most of the remainder of the Eighteenth Century expanded the list of death eligible crimes to include counterfeiting, remaining on or settling lands not purchased from the Native Americans, and larceny. ${ }^{18}$

The first Constitution of the Commonwealth of Pennsylvania, adopted in 1776 , instructed the state legislature to restrict the number of capital crimes. ${ }^{19}$

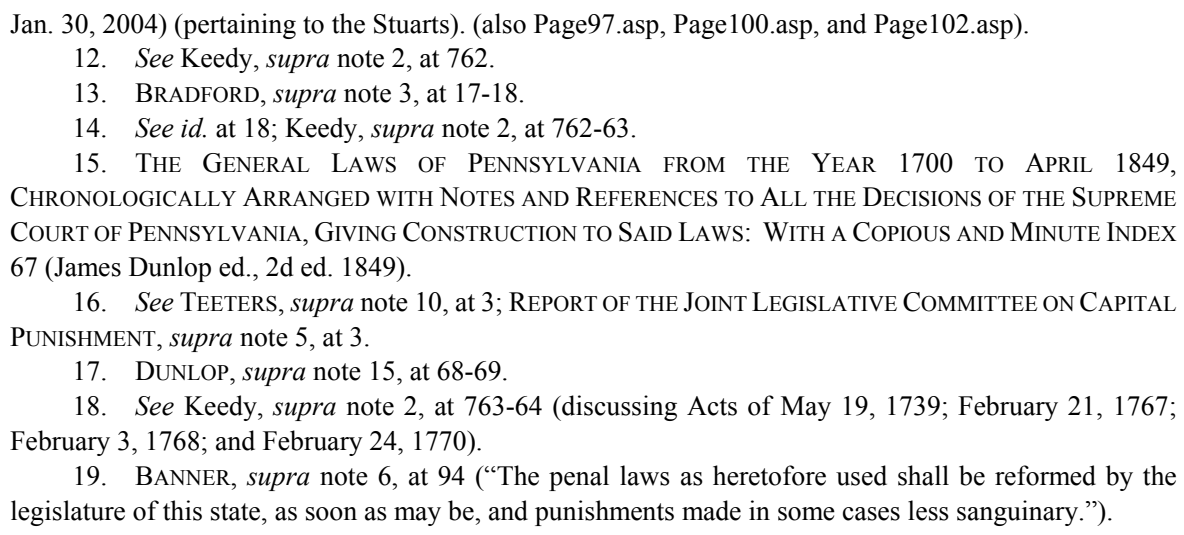


The legislature reacted in relatively short stead, eliminating the crimes of buggery/sodomy, robbery, and burglary from the list of offenses punishable by death, ${ }^{20}$ but not before Joseph Ross, from Westmoreland County, was executed on December 20, 1785, for buggery, ${ }^{21}$ the last person to be executed for a "crime against nature" in the United States. ${ }^{22}$ In passing this amendment, the legislature on September 15, 1786, explained that the death penalty did not work as a deterrent for those crimes and, therefore, persons guilty thereof should be subjected to hard labor, not death. ${ }^{23}$

The most sweeping reform to the penal laws came on April 22, 1794, when the General Assembly enacted "An Act for the Better Preventing of Crimes, and for Abolishing the Punishment of Death in Certain Cases." 24 The Act provided that "[n]o crime whatsoever, hereafter committed, (except murder of the first degree), shall be punished with death in the state of Pennsylvania." 25 Truly remarkable, however, was the portion of the legislation that created degrees of murder, making Pennsylvania the first jurisdiction with a foundation in English law to make such a differentiation. ${ }^{26}$ The Act specifically declared in Section II:

[W] hereas the several offences, which are included under the general denomination of murder, differ so greatly from each other in the degree of their atrociousness, that it is unjust to involve them in the same punishment: That all murder, which shall be perpetrated by means of poison, or lying in wait, or by any other kind of wilful, deliberate and premeditated killing, or which shall be committed in the perpetration or attempt to perpetrate any arson, rape, robbery, or burglary, shall be deemed murder of the first degree; and all other kinds of murder shall be deemed murder in the second degree; and the jury, before whom any person indicted for murder shall be tried, shall, if they find such person guilty thereof, ascertain in their verdict, whether it be murder of the first or second degree; but if such person shall be convicted by confession, the court shall proceed, by examination of witnesses, to determine the degree of the crime, and to give sentence accordingly. ${ }^{27}$

20. BRADFORD, supra note 3, at 20.

21. 15 Minutes of the Supreme EXeCUtive Council of Pennsylvania, From Its Organization TO THE TERMINATION OF THE REVOLUTION 588 (1853).

22. BANNER, supra note 6, at 97.

23. DUNLOP, supra note 15 , at 152 .

24. Id. at 202-204.

25. Id. at 202 .

26. BANNER, supra note 6, at 98; TEETERS, supra note 10, at 3; REPORT OF THE JOINT LEGISLATIVE COMMITTEE ON CAPITAL PUNISHMENT, supra note 5, at 3-4; see also Woodson v. North Carolina, 428 U.S. 280, 290 (1976); Commonwealth v. Zettlemoyer, 454 A.2d 937, 968 (Рa. 1982).

27. DUNLOP, supra note 15, at 202-03. 
The Act further provided, in Section XV, that "[e]very person convicted of murder, of the first degree, his or her aiders, abettors and counsellors, shall suffer death by hanging by the neck." 28

By the 1820 s, a tripartite class system had developed and the middle class, aspiring to be as "respectable" and "genteel" as the rich, developed an aversion to the sight of death and dying, finding the suffering of others not appropriate for spectacle. ${ }^{29}$ The middle class began to look down upon the "vulgar mob's" enjoyment of public executions. ${ }^{30}$ Moreover, the use of public executions was seldom effective in deterring crime, and in fact, often "incited" crime. ${ }^{31}$ Banner explains:

If the crowd was a mob oblivious to the moral lesson a hanging was supposed to impart, it followed that public executions had ceased to serve their original purposes of deterrence and retribution. "To the ignorant and unenlightened" who watched hangings, death was exciting, not frightening. Worse, spectators like these were precisely the ones inclined to sympathize unduly with criminals and the ones most likely to commit crimes themselves after watching a public display of violence. Delivering a message of retribution required that the spectators at a hanging acknowledge the legitimacy of the state and the justice of the criminal law, but a rowdy crowd of drunkards appeared to respect neither. The new perception of the crowd reinforced older critiques of public punishment to create a wave of opposition to public hangings in the first half of the nineteenth century. ${ }^{32}$

In Lancaster on October 25, 1822, John Lechler was executed in front of between twenty and thirty thousand spectators. ${ }^{33}$ Immediately after watching Lechler's execution, fifteen members of the "vulgar mob" were sent to prison for crimes ranging from vagrancy to murder. ${ }^{34}$ The incidents surrounding Lechler's execution led the Pennsylvania legislature in 1824 to consider the abolition of public executions, though the measure did not succeed at that time. $^{35}$ The General Assembly finally passed an "Act to Abolish Public

28. Id. at 204. The crime of murder in the second degree, as well as all other crimes that were considered capital prior to 1794, were punishable with terms of imprisonment. See BANNER, supra note 6, at 98 .

29. BANNER, supra note 6, at 153.

30. Id.

31. John D. Bessler, Death in the Dark: Midnight ExeCutions in America 28 (1997).

32. BANNER, supra note 6, at 154 (internal footnote omitted) (quoting On Capital Punishments: from Judge Brackenridge's Law Miscellanies, 2 CAROLINA LAW REPOSITORY 61 (1815)).

33. BESSLER, supra note 31 , at 23; TEETERS, supra note 10, at 53.

34. BESSLER, supra note 31 , at 28 .

35. Id. at 40 (explaining that the Pennsylvania Senate expressed its belief that public executions were "inexpedient, highly demoralizing, and a great and unnecessary waste of public time and labor"); see also BANNER, supra note 6, at 151 . 
Executions" on April 10, 1834, ${ }^{36}$ which moved hangings from a public locale to within the confines of the penitentiary in the county where the court rendered Judgment of Sentence on the condemned. ${ }^{37}$

By Act approved on June 19, 1913, all executions in the Commonwealth were moved from the prison in the county of conviction to the soon-to-beconstructed State Correctional Institution at Rockview in Centre County. ${ }^{38}$ The Act explained that executions "in every case, must be inflicted by causing to pass through the body of the convict a current of electricity of intensity sufficient to cause death, and the application of such current must be continued until such convict is dead." 39

Over the first half of the twentieth century, the state legislature acted numerous times to expand the class of capital crimes, adding to the definition of first degree murder: (1) death resulting from malicious injury to railroads $;{ }^{40}$ (2) death occurring during the commission of a kidnapping ${ }^{41}$ and (3) death resulting from sabotage of real or personal property, or defectively produced articles, during war or national emergency. ${ }^{42}$ Then, in 1953, the General

36. DuNLOP, supra note 15, at 605-06 ("That whenever hereafter any person shall be condemned to suffer death by hanging for any crime of which he or she shall have been convicted, the said punishment shall be inflicted on him or her within the walls or yard of the jail of the county in which he or she shall have been convicted; and it shall be the duty of the sheriff or coroner of the said county to attend and be present at such execution ....").

37. This legislation was prompted by reports of drinking and gambling at the public execution of Joel Clough in New Jersey in 1833. See BANNER, supra note 6, at 152.

38. Act of June 19, 1913, No. 338, § 1, 1913 Pa. Laws 528

39. Id.

40. Act of June 1, 1911, § 1, 1911 Pa. Laws 553-54. The Act provided:

That if any person shall wilfully and maliciously put, place, cast, or throw upon or across any railroad in this Commonwealth any wood, stone, or other matter or thing; or shall wilfully and maliciously take up, remove, or displace any rail, sleeper, or other matter or thing belonging to any such railroad; or shall wilfully and maliciously turn, move, or divert any switch, machinery, or other appliance belonging to any such railroad; or shall wilfully and maliciously make or show, hide or remove, any signal or light upon or near any such railroad; or shall wilfully and maliciously cast, throw, or cause to fall or strike against, into, or upon any engine, tender, carriage, car, or truck, upon any such railroad, any wood, stone, or other matter or thing; or shall wilfully and maliciously attempt to do or cause to be done any other matter or thing, in any of the cases aforesaid, to obstruct, upset, derail, overthrow, injure, or destroy any engine, tender, carriage, car, or truck used on any such railroad, or to endanger the safety of any person or employe traveling or working or being upon any such railroad, - every such offense shall constitute the offense of malicious injury to railroads ... and in every case where the life of a human being shall be destroyed by or as a result of any of the acts herein prohibited, the offender shall be deemed guilty of murder in the first degree, and upon conviction thereof shall suffer death.

41. Act of May 22, 1923, No. 199, § 74, 1923 Pa. Laws 306.

42. Act of Mar. 29, 1951, No. 15, §§ 2-3, 1951 Pa. Laws 59-60. The Sabotage Prevention Act of March 29, 1951, stated in relevant part: 
Assembly provided a possible death sentence for instances where a prisoner serving a life sentence assaults another person with the intent to kill that other person. ${ }^{43}$ This was the first (and only) time since the sweeping reforms of 1794 that this Commonwealth entertained capital punishment for a crime where the victim does not die.

During the same time period, the legislature embraced a growing wave of statutory enactments in other jurisdictions permitting the jury or the trial court to set the penalty for a conviction of a capital crime at either death or life imprisonment, rather than imposing a mandatory death sentence. By an Act dated May 14, 1925, the General Assembly provided:

That every person convicted of the crime of murder of the first degree . . . shall be sentenced to suffer death ... in the manner provided by law, or to undergo imprisonment for life, at the discretion of the jury trying the case, which shall fix the penalty by its

Section 2. Destroying or Injuring Real and Personal Property.-Whoever, with intent to injure, interfere with, or obstruct the United States, any associate nation, this State, or any other state, in defense, or in preparing for, or carrying on war, or whoever, with reason to believe that his act may injure, interfere with, or obstruct the United States, any associate nation, this State, or any other state, in defense, or in preparing for, or carrying on war during a period of national emergency or war, shall wilfully injure or destroy or shall attempt to so injure or destroy any [real or personal property within this State is guilty of a felony .... .... (alteration in original).

Section 3. Making or Causing Articles to Be Made in Defective Manner First Degree Murder.-Whoever, with intent to injure, interfere with, or obstruct the United States, any associate nation, this State, or any other state, in defense, or in preparing for, or carrying on war, or whoever, with reason to believe that his act may injure, interfere with, or obstruct the United States, any associate nation, this State, or any other state, in defense, or in preparing for, or carrying on war during a period of national emergency or war, shall wilfully make or cause to be made in a defective manner or attempt to make or cause to be made in a defective manner any [article or thing which he has reasonable grounds to believe is intended to be used in connection with defense or with the prosecution of war] . . is guilty of a felony. ... (alteration in original).

Section 3.1. Murder in the First Degree; Limitation of Indictments and Prosecutions. - (a) In every case where the life of a human being is destroyed by, or as a result of, any of the acts prohibited in sections two and three of this act, the offender shall be deemed guilty of murder in the first degree; (b) Indictments and prosecutions may be brought and exhibited for any violation of sections two and three of this act at any time during the life of the violator.

43. Act of July 29, 1953, No. 403, § 710.2, 1953 Pa. Laws 1422. The Act stated in relevant part: Every person who has been sentenced to imprisonment for life in any penal institution located in this Commonwealth, and whose sentence has not been commuted, who commits an assault with intent to kill upon another with a deadly weapon or instrument, or by any means or force likely to produce great bodily injury, is guilty of a felony, and, upon conviction thereof, shall be sentenced to suffer death in the manner provided by law, or to undergo imprisonment for life, at the discretion of the jury trying the case, which shall fix the penalty by its verdict. The court shall impose the sentence so fixed as in other cases. In cases of pleas of guilty, the court shall, at its discretion, impose sentence of death or imprisonment for life.

Id. The discretion of the fact-finder to set the penalty at life imprisonment, rather than death, is a function of the Act of May 14, 1925, discussed infra. 
verdict.... In cases of pleas of guilty, the court, where it determines the crime to be murder of the first degree, shall, at its discretion, impose sentence of death or imprisonment for life. ${ }^{4}$

The states, starting with Tennessee in 1838, were reacting to a growing phenomenon whereby juries "on occasion took the law into their own hands in cases [where the murder was] 'willful, deliberate, and premeditated' in any view of that phrase, but which nevertheless were clearly inappropriate for the death penalty. In such cases, [the juries] simply refused to convict of the capital offense." 45

By virtue of the Act of 1925, Pennsylvania juries were "empowered to decide, on a case-by-case basis, whether life or death was the appropriate sentence" for a first-degree murder conviction. ${ }^{46}$ Pursuant to the Act, juries were required to return a singular verdict as to both guilt and punishment; they were instructed to ascertain guilt first and, if they found the defendant guilty of first-degree murder, thereafter, consider whether the defendant should be executed or imprisoned for the remainder of his or her natural life. ${ }^{47}$ Likewise, where the defendant pleaded guilty to homicide, if the court determined that the defendant was guilty of first-degree murder, it would then consider what punishment to impose. ${ }^{48}$

44. Act of May 14, 1925, No. 411, § 75, 1925 Pa. Laws 759.

45. McGautha v. California, 402 U.S. 183, 199 (1971); see also Woodson v. North Carolina, 428 U.S. 290, 290 (1976); Note, The Penalty in Pennsylvania for Murder in the First Degree, 7 TEMP. L.Q. 330, 330 (1933) [hereinafter Note, The Penalty]

[U]p until the passage of the Act of May 14, 1925, the province of the jury was merely to determine the degree of murder from the evidence, the jury automatically, by its rendition inflicting the punishment of death in first degree murder cases. Any recommendation for leniency had to be made to the Board of Pardons, as prior to the Act of May 14, 1925, neither the court nor the jury had any discretion in fixing the penalty for first degree murder. Due to this restriction, juries were reluctant to inflict the death penalty in cases where they felt a lighter punishment should be inflicted because of extenuating circumstances, and as it was mandatory that the death penalty should be inflicted if there was a verdict of guilty of first degree murder, the jury with the natural reluctance of most men under similar circumstances, would often return a verdict of guilty of homicide in some lesser degree.

Id.; BANNER, supra note 6, at 214-15.

46. BANNER, supra note 6, at 215. Pennsylvania was not the last state to enact such a statute- $-\mathrm{New}$ York did not grant the power to avoid imposing the death penalty in first-degree murder cases until 1963. Id.

47. Note, The Penalty, supra note 45, at 332-33; see also Commonwealth v. Curry, 135 A. 316, 317 (Pa. 1926).

48. See Commonwealth v. Williams, 166 A.2d 44, 47 (Pa. 1960), cert. denied sub nom.; Cater v. Pennsylvania, 366 U.S. 914 (1961); Rivers v. Pennsylvania, 366 U.S. 915 (1961). Interestingly, a local court rule in Philadelphia County provided that "[p]leas of guilty to indictments for murder shall be heard by a court en banc, consisting of the judge before whom the plea is entered and two other judges, who shall 
In Commonwealth v. Parker, ${ }^{49}$ the Supreme Court of Pennsylvania considered bifurcating the proceedings to allow the jury to hear evidence pertaining to guilt, determine guilt, and then, where appropriate, hear evidence relevant to sentencing and set the penalty. The three defendants in Parker argued that the jury determining the guilt of a defendant should not be privy to prior offenses committed by that defendant having nothing to do with the offense presently charged. ${ }^{50}$ They averred that a jury would not be able to store away evidence of prior crimes until it came time to consider the penalty and, instead, would inevitably use that evidence in ascertaining the guilt of the defendant. Specifically, they alleged that the trial court should keep from the jury those portions of their confessions dealing with disassociated prior crimes and not reveal such unless and until the jury determined that they were in fact guilty of first-degree murder. ${ }^{51}$ The court rejected these contentions, finding no statutory authority that would permit juries to "render piecemeal verdicts." 52 The court explained its holding as follows:

It may be that, if under any circumstances evidence of other offenses than the one on trial is admitted as helpful to the jury in the performance of its duty in assessing the punishment, such proof will inevitably be used by it in determining the guilt of the prisoner. This is not an insurmountable objection. . . Here the statute requires the jurors to assess the punishment, and permits them to extend mercy, in what appears to them as a proper case, by reducing the penalty to life imprisonment; but there is no provision for a separate inquiry as to the fact of whether or not the defendant is entitled to such mercy, nor is there any evidence that the statute intended there should be such a separate inquiry.

The act of 1925 was not passed to help habitual criminals, and we take judicial [notice] of the fact that offenders of that designation have become so general that the law, not

be called in by him" to fix the degree of guilt and, where appropriate, decide between a sentence of life imprisonment or death. Id. (citing Rule 43 of the Court of Oyer and Terminer and General Jail Delivery and Quarter Sessions of the Peace of Philadelphia). If two judges agreed that death was the appropriate penalty, the defendant was sentenced to death. Commonwealth v. Scoleri, 202 A.2d 521, 536 (Pa. 1964) (citing Commonwealth v. Cole, 119 A.2d 253 (Pa. 1956) and Commonwealth v. Petrillo, 16 A.2d 50 (Pa. 1940)), petition for modification denied, 203 A.2d 319 ( $\mathrm{Pa}$. 1964). There was no constitutional requirement for a three-judge panel in such situations; in the absence of a rule similar to the one promulgated in Philadelphia County, a single jurist was empowered to determine guilt and the penalty, including, where appropriate, sentencing a defendant to death. Williams, $166 \mathrm{~A} .2 \mathrm{~d}$ at 47.

49. Commonwealth v. Parker, 143 A. 904, 907 (Pa. 1928).

50. $I d$.

51. Id. at 906 . In 1923 the only capital crime was first-degree murder. See notes $40-43$ supra and their accompanying text.

52. Id. at 907; see also Commonwealth v. Jones, 50 A.2d 342, 344 (Pa. 1947) ("It is well settled that evidence in proper form of prior convictions of crime is admissible in homicide cases, for the sole purpose of aiding the jury in determining the penalty to be inflicted if it finds the accused guilty of murder in the first degree...."). 
only lex scripta but non scripta, must advance to protect society against them. This being so, in a case like the present, where the trial judge was convinced from the confessions of the defendants, as the court below evidently was, that they were habitual offenders against society — robbers, burglars, and, as occasion arose, murderers - where the evidence indicated such to be their general manner of life, and where the defendants asked that, if convicted, the jury, in assessing punishment, extend mercy to them, we cannot say it was reversible error to receive their full confessions in evidence, even though it is possible that the admissions therein of other offenses may have militated in a general way against defendants. ${ }^{53}$

The Parker court believed that a basic limiting instruction to the jury, explaining that they could only consider evidence of prior crimes to determine penalty, and only after finding the defendant guilty of first-degree murder, was sufficient to guard against the improper use of such evidence.

The rule the Supreme Court of Pennsylvania announced in Parker, the socalled "Parker Rule," was "uniformly followed" by the courts of the Commonwealth, ${ }^{54}$ but it engendered significant criticism from legal commentators. ${ }^{55}$ One scholar noted that there is nothing in the legislation of

53. Parker, 143 A. at 907.

54. See Commonwealth v. McCoy, 172 A.2d 795, 797 (Pa. 1961) (alluding to the admissibility of prior convictions in murder trials); see, e.g., Commonwealth v. Thompson, 184 A. 97 (Pa. 1936):

At the trial the $[\mathrm{C}]$ ommonwealth placed in evidence the records of eight prior convictions of the defendant for burglary, in all of which instances he had pleaded guilty and had been sentenced. The trial judge, in instructing the jury as to the use they might make of this evidence, charged in the most careful manner that it was to be considered only for the purpose of fixing the penalty at death or life imprisonment in case they should find the defendant guilty of murder in the first degree.... The evidence of these convictions was presented to show that the defendant was an habitual offender against society, who regularly engaged in crimes of violence for mercenary purposes. It was, therefore, the fact of his conviction [that] was of importance. The mode of conviction, whether by plea of guilty or trial before a jury, was a matter of no moment. The use of these records at trial was limited by the trial judge to the purposes intended by the Act of May 14, $1925 \ldots$ and in conformity with the principles laid down in the recent decisions of this Court [string-citing cases, including Parker]. We see no error in this instruction.

Id. at 99 (internal citations modified or omitted); see also Commonwealth v. Williams, 160 A. 602 (Pa. 1932):

There can be little doubt that the admission of a prior conviction trenches very strongly on the fundamental rule of evidence, that a distinct crime unconnected with that on trial cannot be given in evidence against a prisoner as proof of the crime on trial; it shows a moral disposition to commit crime. But, as stated in [Parker], the law must advance to protect society against habitual criminals.

Id. at 608. But see People v. Witt, 148 P. 928, 930-31 (Cal. 1915) (adopting the opposite approach); Commonwealth v. Dague, 152 A. 839, 839 (Pa. 1930) (holding the jury is entitled to hear "testimony ... offered to enable [it] to know what manner of man the defendant was, if they should find him guilty of murder of the first degree, when it [comes] to the exercise of their discretion on the question of his punishment....”).

55. See, e.g., Robert E. Knowlton, Problems of Jury Discretion in Capital Cases, 101 U. PA. L. REv. 1099, 1108-16 (1953); Note, The Penalty, supra note 45, at 337-40 (explaining also that a jury should not be privy to mitigating evidence during the guilt phase of a trial); $(f$. REPORT OF THE JOINT LEGISLATIVE 
1925 to indicate that the legislature favored a schema whereby the Commonwealth would be able to obtain a first-degree murder conviction on the surfeit of the defendant's prior criminal record. ${ }^{56}$ In Commonwealth $v$. McCoy, even the Pennsylvania Supreme Court accepted the assailments, seeming to acquiesce "that it is impossible by a mere cautionary instruction to the jury to obliterate from the minds of its members the prejudicial impressions registered by the introduction of evidence concerning prior disassociated criminal conduct of the defendant ...."57 The legislature attempted to remedy this situation by a 1947 bill, ${ }^{58}$ but the Supreme Court of Pennsylvania subsequently determined that the Act was unconstitutional because of defects in the title of the legislation. ${ }^{59}$

Ultimately, by Act of December 1, 1959, the General Assembly enacted the "Split Verdict" law, which bifurcated the proceedings in potential firstdegree murder trials. ${ }^{60}$ In McCoy, the Pennsylvania Supreme Court explained

Committee on CAPital Punishment, supra note 5, at 4 ("This Act of 1925 brought trouble in its wake. Since the jury had the duty to fix the penalty, it was permitted by judicial decision to hear, even while considering the issue of his guilt, additional evidence as to defendant's previous bad character.").

56. Knowlton, supra note 55, at 1114.

57. McCoy, 172 A.2d at 797.

58. Act of July 3, 1947, 1947 Pa. Laws 1239 (amending the Act of March 15, 1911, 1911 Pa. Laws 20, 19 Pa. Stat. § 711).

59. Commonwealth v. DePofi, 66 A.2d 649, 656 (Pa. 1949), cert. denied, 338 U.S. 852 (1949).

60. Act of Dec. 1, 1959, No. 594, § 701, 1959 Pa. Laws, 1621-23. That statute provided in relevant part as follows:

Whoever is convicted of the crime of murder of the first degree is guilty of a felony and shall be sentenced to suffer death in the manner provided by law, or to undergo imprisonment for life, at the discretion of the jury trying the case .... which shall, in the manner hereinafter provided, fix the penalty. In the trial of an indictment for murder, the court shall inform the jury that if they find the defendant guilty of murder in the first degree, it will be their further duty to fix the penalty therefor, after hearing such additional evidence as may be submitted upon that question. Whenever the jury shall agree upon a verdict of murder of the first degree, they shall immediately return and render the same, which shall be recorded, and shall not thereafter be subject to reconsideration by the jury, or any member thereof. After such verdict is recorded and before the jury is permitted to separate, the court shall proceed to receive such additional evidence not previously received in the trial as may be relevant and admissible upon the question of the penalty to be imposed upon the defendant, and shall permit such argument by counsel, and deliver such charge thereon as may be just and proper in the circumstances. The jury shall then retire and consider the penalty to be imposed and render such verdict respecting it as they shall agree upon. A failure of the jury to agree upon the penalty to be imposed, shall not be held to impeach or in any way affect the validity of the verdict already recorded, and whenever the court shall be of opinion that further deliberation by the jury will not result in an agreement upon the penalty to be imposed, it may, in its discretion, discharge the jury from further consideration thereof, in which event if no retrial of the indictment is directed, the court shall sentence the defendant to life imprisonment upon the verdict theretofore rendered by the jury, and recorded as aforesaid. The court shall impose the sentence so fixed as in other cases. In cases of pleas of guilty, the court where it determines the crime to be murder of the first degree, 
that the purpose of the Split Verdict law was "to insure that the defendant in a murder case will be tried on the issue of his guilt or innocence of the crime charged, free from any possible prejudicial effect which might arise from the introduction in evidence of his past unrelated criminal record." ${ }^{61}$ Pursuant to the 1959 enactment, the jury would first consider guilt and render a verdict on guilt. If it determined that the defendant was guilty of first-degree murder, only then would evidence irrelevant to guilt be brought before the jury, who would listen to the penalty evidence and retire to consider whether the defendant should be incarcerated for life or sentenced to die. ${ }^{62}$

The Pennsylvania Supreme Court instructed courts and juries alike, when setting the penalty for a first-degree murder conviction, to consider the nature of the crime, the circumstances surrounding the crime, and all of the evidence to determine what kind of person the defendant was at the time of the offense. ${ }^{63}$ "In a capital case where a man's life is at stake, it is imperative that the death penalty be imposed only on the most reliable evidence. Prior convictions of record, and constitutionally valid admissions and confessions of other crimes [which would not be admissible when determining guilt] meet this standard of reliability." $" 64$ The court recognized that this test is relatively without standard, though "it is certainly true that a jury which returns with a sentence of life imprisonment has determined that the facts in the case do not warrant [the] death penalty." ${ }^{65}$ Even still, the courts of the Commonwealth were not empowered to overturn duly rendered jury verdicts. ${ }^{66}$

In 1972, the Supreme Court of the United States in the case of Furman v. Georgia $^{67}$ found that, as applied at that time, the death penalty constituted

shall, at its discretion, impose sentence of death or imprisonment for life.

Id. The 1959 act amended an Act passed on June 24, 1939, "to consolidate, amend and revise the penal laws of the Commonwealth." Act of June 24, 1939, No. 375, 1939 Pa. Laws, 872-1075 (revising the 1939 Act due to its merely having recodified the statutory language approved in 1925).

61. McCoy, 172 A.2d at 797.

62. Report of the Joint Legislative Committee on CAPital Punishment, supra note 5, at 5.

63. Commonwealth v. Bell, 208 A.2d 465, 468 (Pa. 1965) (explaining that a jury "should have the benefit of all such evidence and weigh carefully the same factors [as the court would]"); Commonwealth v. Melton, 178 A.2d 728, 732 (Pa. 1962) (discussing the duty of a court after a guilty plea), cert. denied, 371 U.S. 851 (1962).

64. Commonwealth v. Hoss, 283 A.2d 58, 69 (Pa. 1971).

65. Commonwealth v. Littlejohn, 250 A.2d 811, 816 (Pa. 1969), called into question on other grounds, Commonwealth v. Martorano, 634 A.2d 1063 (Pa. 1993).

66. See Commonwealth v. Smith, 176 A.2d 619, 621 (Pa. 1962) (reiterating that "a Court has no power to reverse or reduce the verdict of a jury which has lawfully imposed the penalty of death, on the ground of abuse of discretion, or because defendant was a moron, or had an irresistible impulse, or was a sexual pervert, or was a criminally inclined psychopath, or for any similar psychotic reason").

67. Furman v. Georgia, 408 U.S. 238 (1972). 
"cruel and unusual punishment" and, therefore, violated the Eighth and the Fourteenth Amendments to the U.S. Constitution. ${ }^{68}$ On the same day that Furman was announced, the United States Supreme Court vacated several death penalty sentences imposed in Pennsylvania ${ }^{69}$ pursuant to the Act of 1939, as amended by the Act of 1959, implicating that, akin to its Georgian counterpart, the Pennsylvania statutory scheme was unlawful. ${ }^{70}$ Indeed, later that year, in Commonwealth v. Bradley, ${ }^{71}$ the Supreme Court of Pennsylvania found the death penalty provisions of the Act of 1939, as amended by the Act of 1959, to be unconstitutional in light of Furman. ${ }^{72}$ Thereafter, "Bradley's interpretation of the Furman decision [was] consistently followed and death sentences imposed [pursuant to the Act of 1939 were] vacated in every case ..." that came before the Pennsylvania Supreme Court. ${ }^{73}$ Any attempted arguments that the evidentiary record of the individual cases revealed no evidence of "discrimination in the imposition of the death penalty on the basis of race, wealth, or nature of the proceeding leading to [the] conviction," were summarily rejected. ${ }^{74}$

"[R] espond[ing] to the void in Pennsylvania law regarding imposition of a death penalty" ${ }^{\prime 75}$ created by Bradley, the Legislature quickly enacted Section 1102 of the Crimes Code, ${ }^{76}$ which provided in toto that "[a] person who has been convicted of a murder of the first degree shall be sentenced to death or to a term of life imprisonment." 77

68. Id. at $239-40$.

69. See Phelan v. Brierly, 408 U.S. 939 (1972); Scoleri v. Pennsylvania, 408 U.S. 934 (1972).

70. See Commonwealth v. McKenna, 383 A.2d 174, 177 (Pa. 1978) (stating that the unconstitutionality of the Pennsylvania capital sentencing scheme "was virtually fore-ordained by the Supreme Court of the United States when, on the same day that it announced its decision in Furman, the Court vacated sentences" in Phelan and Scoleri).

71. Commonwealth v. Bradley, 295 A.2d 842 (Pa. 1972).

72. Id. at 845. It appears that even before Furman, in a 1971 opinion, Pennsylvania Attorney General Fred Speaker declared the Pennsylvania death penalty statute unconstitutional. However, "[s]hortly afterward, newly appointed Attorney General J. Shane Creamer rescinded Speaker's opinion, concluding that the fate of the death penalty should be decided by the legislature or the courts, not by the [A]ttorney [G]eneral." Pennsylvania Department of Corrections, History of the Death Penalty in Pennsylvania, at http://www.cor.state.pa.us/death.html (last visited Jan. 30, 2004) [hereinafter Pa. DOC, History].

73. Commonwealth v. Martin, 348 A.2d 391, 414 (Pa. 1975), cert. denied, 428 U.S. 923 (1976) (plurality opinion) (modification added); see also McKenna, 383 A.2d at 177-78; Commonwealth v. Scoggins, 304 A.2d 102, 108 (Pa. 1973); Commonwealth v. Lopinson, 296 A.2d 524, 525 (Pa. 1972); Commonwealth v. Ross, 296 A.2d 629, 630 (Pa. 1972); Commonwealth v. Sharpe, 296 A.2d 519, 524 (Pa. 1972).

74. Martin, 340 A.2d at 415 (quoting Commonwealth v. Dobrolenski, 334 A.2d 268, 274 (Pa. 1975)).

75. Commonwealth v. Zettlemoyer, 452 A.2d 937, 949 (Pa. 1982); McKenna, 383 A.2d at 178.

76. 18 PA. CONS. StAT. ANN. § 1102 (West 1972).

77. $I d$. 
In January of 1973, Governor Milton J. Shapp, by way of the Pennsylvania Attorney General Israel Packel, initiated the creation of the Governor's Study Commission ("Commission") that was to conduct a comprehensive study on capital punishment. ${ }^{78}$ The work of the Commission culminated in a bifurcated report by the majority and the minority of the appointed commissioners. ${ }^{79}$ The majority concluded that "the death penalty [wa]s not needed, [wa]s undesirable, [wa]s offensive to a significant segment of our population, and its existence would do more harm than good." 80 Conversely, the minority report recommended the continued use of capital punishment "in only the most outrageous cases of murder."

Despite the report of the Commission, apparently unsatisfied with its earlier effort, in 1974, the legislature again sought to comply with Bradley and Furman by enacting Section 1311 of the Sentencing Code ${ }^{82}$ over the veto of

78. REPORT OF THE GOVERNOR's STUDy COMMISSION ON CAPITAL PUNISHMENT 1 (1973).

79. Id. at 3 .

80. Id. at 27

81. Id. at 76 .

82. 18 PA. Cons. Stat. AnN. $§ 1311$ (West 1974) (adopted by Act of Mar. 26, 1974, No. 46, $\S 1311(\mathrm{a})-(\mathrm{e}), 1974 \mathrm{~Pa}$. Laws 214). Section 1311 provided in relevant part as follows:

(a) Findings by jury.-The jury before whom any person shall be tried for murder, shall, if they find such person guilty thereof, ascertain in their verdict whether the person is guilty of murder of the first degree, murder of the second degree or murder of the third degree.

(b) Instructions to jury and recording verdict.- In a trial for murder, the court shall inform the jury prior to their deliberations, as to the penalties for murder of the first degree, murder of the second degree and murder of the third degree. The court shall also inform the jury that if they find the defendant guilty of murder of the first degree, it will be their further duty to determine whether the killing was accompanied by any aggravating or mitigating circumstances as set forth in subsection (d) of this section after hearing such additional evidence as may be submitted upon that question. (c) Procedure at sentencing hearings.-After such verdict is recorded and before the jury is permitted to separate, the court shall proceed to receive such additional evidence not previously received from the trial as may be relevant and admissible upon the question of aggravating and mitigating circumstances and shall permit such argument by counsel, and deliver such charge thereon as may be just and proper in the circumstances. Aggravating circumstances must be proved beyond a reasonable doubt. Mitigating circumstances must be proved by a preponderance of the evidence. The jury shall then retire and consider the aggravating and mitigating circumstances and render such verdict respecting them as they shall agree upon. A failure of the jury to agree upon the aggravating and mitigating circumstances shall not be held to impeach or in any way affect the validity of the verdict already recorded, and whenever the court shall be of the opinion that further deliberation by the jury will not result in an agreement upon the aggravating and mitigating circumstances, it may, in its discretion, discharge the jury from further consideration thereof, in which event if no retrial is directed, the court shall sentence the defendant to life imprisonment ....

(d) Aggravating and mitigating circumstances.-If a murder of the first degree is accompanied by at least one of the following aggravating circumstances and none of the following mitigating circumstances, the person convicted shall be sentenced to death. If a murder of the first degree is not accompanied by any of the following aggravating circumstances or is accompanied by at least 
Governor Shapp. ${ }^{83}$ The Pennsylvania judiciary, however, soon invalidated Section 1311, as well as its predecessor-Section 1102. First, Commonwealth v. Moody ${ }^{84}$ struck down Section 1311, finding that the statute "so narrowly limit[ed] the circumstances which the jury may consider mitigating that it preclud[ed] the jury from a constitutionally adequate consideration of the character and record of the defendant." ${ }^{" 85}$ Thereafter, in Commonwealth $v$. McKenna ${ }^{86}$ the Supreme Court of Pennsylvania found Section 1102 to be unconstitutional, observing that "[this] section, stark in its brevity, was

one of the following mitigating circumstances the person convicted shall be sentenced to life imprisonment:

(1) Aggravating circumstances:

(i) The victim was a fireman, peace officer, or public servant concerned in official detention

... who was killed in the performance of his duties.

(ii) The defendant paid or was paid by another person or had contracted to pay or be paid by another person or had conspired to pay or be paid by another person for the killing of the victim.

(iii) The victim was being held by the defendant for ransom or reward, or as a shield or hostage.

(iv) The death of the victim occurred while defendant was engaged in the hijacking of an aircraft.

(v) The victim was a witness to a murder or other felony committed by the defendant and was killed for the purpose of preventing his testimony against the defendant in any grand jury or criminal proceeding involving such offenses.

(vi) The defendant committed a killing while in the perpetration of a felony.

(vii) In the commission of the offense the defendant knowingly created a grave risk of death to another person in addition to the victim of the offense.

(viii) The offense was committed by means of torture.

(ix) The defendant has been convicted of another Federal or State offense, committed either before or at the time of the offense at issue, for which a sentence of life imprisonment or death was imposable or the defendant was undergoing a sentence of life imprisonment for any reason at the time of the commission of the offense.

(2) Mitigating circumstances:

(i) The age, lack of maturity, or youth of the defendant at the time of the killing.

(ii) The victim was a participant in or consented to the defendant's conduct ... or was a participant in or consented to the killing.

(iii) The defendant was under duress although not such duress as to constitute a defense to prosecution....

(e) Guilty pleas and non-jury trials.- In cases of pleas of guilty, or trial by court, the court shall impose sentence in accordance with Rules of Criminal Procedure as promulgated by the Supreme Court of Pennsylvania.

Act of Mar. 26, 1974, No. 46, 1974 Pa. Laws 213-16.

83. Pa. DOC, History, supra note 72.

84. Commonwealth v. Moody, 382 A.2d 442 (Pa. 1977), cert. denied, 438 U.S. 914 (1978).

85. Id. at 447 .

86. See Commonwealth v. McKenna, 383 A.2d 174, 177 (Pa. 1978). 
distinguished by a complete lack of direction as to the circumstances that would warrant imposition of the death penalty." 87

In the meantime, four years after Furman, in Gregg v. Georgia, ${ }^{88}$ the United States Supreme Court found that guided discretion schemes for imposing the death penalty were constitutional. Following Moody and McKenna, faced with another void in death penalty legislation, and guided by the Gregg analysis, on September 13, 1978, the Pennsylvania legislature, again over the veto of Governor Shapp, ${ }^{89}$ amended the discarded Section 1311, which was later transferred into Section $9711 . .^{90}$

Section 9711 provided for a split-verdict procedure, wherein, it was first determined whether the defendant was guilty of first-degree murder. ${ }^{91}$ In cases involving a jury returning with such a verdict, a separate "sentencing" proceeding was then conducted before the same jury panel..$^{92}$ Similarly, where the defendant pled guilty or waived his right to a jury trial, the trial court would impanel a jury for the sole purpose of carrying out this proceeding. ${ }^{93}$ During the "sentencing" proceeding, the prosecution and the defense presented arguments and additional evidence relative to the circumstances and the history and character of the defendant. ${ }^{94}$ The trial court would then give the jury instructions concerning the aggravating circumstances specified in Section 9711(d), mitigating circumstances set forth in Section 9711(e), the burdens of proof as to these circumstances, and the weighing process to be performed. ${ }^{95}$ Additionally, Section 9711 provided for automatic appellate review of the death sentence by the Supreme Court of Pennsylvania. ${ }^{96}$

87. Id. at 178 .

88. Gregg v. Georgia, 428 U.S. 153 (1976). Gregg was part of a quintet of capital decisions, announced by the United States Supreme Court on the same day, addressing the constitutionality of capital punishment. See, e.g., Proffitt v. Florida, 428 U.S. 242 (1976); Jurek v. Texas, 428 U.S. 262 (1976); Woodson v. North Carolina, 428 U.S. 280 (1976); Roberts v. Louisiana, 428 U.S. 325 (1976).

89. See Pa. DOC, History, supra note 72.

90. Section 401(a) of the Act of Oct. 5, 1980, No. 142, 1980 Pa. Laws 693, 758, transferred $§ 1311$ to chapter 97 of the Judicial Code, 42 Pa. Cons. Stat. Ann. § 9711 (West 1988). As a matter of expediency, the citations will cite the most up-to-date version of $\S 9711$ rather than the repealed $\S 1311$, unless it has been altered since its passage. In such cases, the original date of transfer will be provided.

91. 42 PA. CONS. StAT. § 9711(a)(1) (2003). The split-verdict procedure was retained from the previous versions of the statute. See Commonwealth v. Zettlemoyer, 454 A.2d 937, 950 (Pa. 1982).

92. See 42 Pa. Cons. StAT. § 9711(d)(a)(1) (2003).

93. Id. § 9711(b).

94. Id. § 9711(d).

95. Id. $\S 9711(\mathrm{c})$.

96. Id. § 9711(h)(1). In addition to being able to correct trial errors, the statute allowed the Supreme Court of Pennsylvania to vacate the sentence if: (1) the sentence "was the product of passion, prejudice or any other arbitrary factor;" (2) "the evidence fail[ed] to support the finding of an aggravating circumstance;" 
As enacted, the statute provided ten aggravating circumstances, including:

(1) The victim was a fireman, peace officer or public servant concerned in official detention ... who was killed in the performance of his duties.

(2) The defendant paid or was paid by another person or had contracted to pay or be paid by another person or has conspired to pay or be paid by another person for the killing of the victim.

(3) The victim was being held by the defendant for ransom or reward, or as a shield or hostage.

(4) The death of the victim occurred while defendant was engaged in the hijacking of an aircraft.

(5) The victim was a prosecution witness to a murder or other felony committed by the defendant and was killed for the purpose of preventing his testimony against the defendant in any grand jury or criminal proceeding involving such offenses.

(6) The defendant committed a killing while in the perpetration of a felony.

(7) In the commission of the offense the defendant knowingly created a grave risk of death to another person in addition to the victim to the offense.

(8) The offense was committed by means of torture.

(9) The defendant has a significant history of felony convictions involving the use or threat of violence to the person.

(10) The defendant has been convicted of another Federal or State offense, committed either before or at the time of the offense at issue, for which a sentence of life imprisonment or death was imposable or the defendant was undergoing a sentence of life imprisonment for any reason at the time of the commission of the offense. ${ }^{97}$

The Commonwealth was required to prove the presence of the aggravating circumstance beyond a reasonable doubt. ${ }^{98}$ Conversely, Section 9711 provided for eight mitigating circumstances and the defendant was required to prove their existence by the preponderance of the evidence. ${ }^{99}$ The mitigating circumstances included the following:

(1) The defendant has no significant history of prior criminal convictions.

(2) The defendant was under the influence of extreme mental or emotional disturbance.

(3) The capacity of the defendant to appreciate the criminality of his conduct or to conform his conduct to the requirements of law was substantially impaired.

(4) The age of the defendant at the time of the crime.

(5) The defendant acted under extreme duress, although not such duress as to constitute a defense to prosecution under $18 \mathrm{~Pa}$. C.S. $\S 309$ (relating to duress), or acted under the substantial domination of another person.

or (3) the sentence was "excessive or disproportionate to the penalty imposed in similar cases considering both the circumstances of the crime and the character and record of the defendant." Id. § 9711(h)(3)(i-iii). The review of the trial record in murder was mandated by the Act of Feb. 15, 1870, No. 6, 1870 Pa. Laws 15. See Commonwealth v. Raymond, 194 A.2d 150, 151-52 (Pa. 1963), cert. denied, 377 U.S. 999 (1964), rehearing denied, 379 U.S. 873 (1964).

97. 42 PA. CONS. STAT. § 9711(d) (1980).

98. Id.

99. 42 Pa. CONS. STAT. § 9711(e) (2003). 
(6) The victim was a participant in the defendant's homicidal conduct or consented to the homicidal acts.

(7) The defendant's participation in the homicidal act was relatively minor.

(8) Any other evidence of mitigation concerning the character and record of the defendant and the circumstances of his offense. ${ }^{100}$

Section 9711 mandated a verdict of death if the jury unanimously found at least one aggravating circumstance and no mitigating circumstances, or unanimously found one or more aggravating circumstances that outweighed any mitigating circumstances. ${ }^{101}$ In all other cases, the defendant was to be sentenced to life imprisonment. ${ }^{102}$

Five years after its enactment, in Commonwealth $v$. Zettlemoyer, a 4-3 decision, ${ }^{103}$ the Supreme Court of Pennsylvania held that Section 9711 satisfied the state and federal constitutional mandates as articulated in Furman, Gregg, and their Pennsylvania progeny. ${ }^{104}$ In the following years, Section 9711 survived multiple constitutional challenges. ${ }^{105}$ It was not until 1990, however, that the United States Supreme Court ruled that the Pennsylvania scheme for capital sentencing satisfied constitutional requirements. ${ }^{106}$

Since the decision of the Pennsylvania Supreme Court in Zettlemoyer, the General Assembly has amended Section 9711 on several occasions. First, in 1986, the legislature added the following two aggravating circumstances:

(11) The defendant has been convicted of another murder committed in any jurisdiction and committed either before or at the time of the offense at issue.

(12) The defendant has been convicted of voluntary manslaughter... or a substantially equivalent crime in any other jurisdiction, committed either before or at the time of the offense at issue. ${ }^{107}$

100. $I d$.

101. Id. § 9711(c)(1)(iv); Commonwealth v. Zettlemoyer, 454 A.2d 937, 951 (Pa. 1982).

102. 42 PA. CONS. STAT. § 9711(f) (1980).

103. Zettlemoyer, 454 A.2d at 937.

104. Zettlemoyer represented the second opportunity that the Supreme Court of Pennsylvania had the occasion to consider the constitutionality of $\S 9711$. See Commonwealth v. Story, 440 A.2d 488 (Pa. 1981). In Story, however, "four [of the seven] Justices ... have determined that the sentencing procedures adopted [in § 9711] were not intended by the legislature to be applied" to the conviction at issue and, therefore, constitutionality of $\S 9711$ was not addressed. Zettlemoyer, 454 A.2d at 941 n.1.

105. See, e.g., Commonwealth v. Breakiron, 729 A.2d 1088, 1096 (Pa. 1999) (holding that the definition of the term "torture" contained in $\S 9711$ (d)(8) was not constitutionally vague), cert. denied, 528 U.S. 1169 (2000); Commonwealth v. Moore, 633 A.2d 1119, 1130 (Pa. 1993) (finding that $§ 9711$ does not violate the Separation of Powers Clause of the Pennsylvania Constitution), cert. denied, 513 U.S. 1114 (1995), rehearing denied, 514 U.S. 1010 (1995).

106. See Blystone v. Pennsylvania, 494 U.S. 299 (1990).

107. 42 Pa. Cons. StAT. $\$ 9711$ (d)(11)-(12) (2003) (adopted by the Act of July 7, 1986, No. 87, § 1, 1986 Pa. Laws 400). 
This amendment was proposed in response to the decision of the Pennsylvania Supreme Court in Commonwealth v. Goins. ${ }^{108}$ In Goins, the defendant argued, inter alia, that his singular prior conviction for third-degree murder was insufficient to support the finding of the jury of the existence of the (d)(9) aggravator, ${ }^{109}$ that he had "a significant history of felony convictions involving the use or threat of violence to the person." $" 110$ The Court accepted this argument and threw out the death sentence, reasoning as follows:

[I]t is important to note that the statute reads "a significant history of felony convictions" rather than "a history of significant felony convictions." The pertinent rule of grammar to be followed is that the modifier should be placed, if possible, next to the word to be modified. If the legislature had intended that the seriousness of the prior felonies be the measure of the aggravating circumstance, the latter construction would have been correctly used. The use of the former construction instead clearly demonstrates the intention that it be the defendant's "history" of felony convictions which is "significant." In this context it appears that the plural form "convictions" is intentionally used to the exclusion of the singular form "conviction." 111

Because the Pennsylvania Supreme Court concluded that the statutory language emphasized the quantum of prior convictions rather than the seriousness of the crimes, the General Assembly promulgated aggravators $(d)(11)$ and $(d)(12) .{ }^{112}$ Several representatives expressed strong reservations ${ }^{113}$

108. Commonwealth v. Goins, 495 A.2d 527 (Pa. 1985), superseded by statute as stated in Commonwealth v. Moran, 636 A.2d 612 (Pa. 1993), cert. denied, 511 U.S. 1152 (1994).

109. Id. at 532 .

110. See 42 Pa. CONS. STAT. $\S 9711$ (d)(9) (2003).

111. Goins, 495 A.2d at 533-34; accord Commonwealth v. Frederick, 498 A.2d 1322, 1326 (Pa. 1985) (holding same for singular prior voluntary manslaughter conviction).

112. See 1986 Legislative Journal-House 1090-91 (June 3, 1986). Representative O’Brien spoke on the floor to explain the then current effect of $\S 9711$ :

Mr. Speaker, this legislation is in response to a July 11 State Supreme Court opinion reversing a lower court death penalty sentence of an individual convicted of killing his wife in 1982 ... Under current law, individuals convicted of first-degree murder can receive the death penalty if they have a significant history of felony convictions involving the use or threat of violence. Justices in the majority opinion [in Goins] interpreted current law to mean quantity rather than seriousness of felony convictions.

Id.

113. See, e.g. id. at 1089 (statements of Reps. O'Donnell and Kukovich). Representative O'Donnell explained:

Now, those of us who have historically supported capital punishment are very concerned, or some of us, myself included, are very concerned that the prospect of lengthening the list of aggravating circumstances for capital punishment may run us afoul of the constitutional test. The current Pennsylvania statute has endured every test of its constitutionality precisely because it has been very limited in its scope. The constitutional test, briefly, is that you must set out both quantitatively and qualitatively a basis other than committing a murder to be able to fall into the aggravating 
concerning the constitutionality of the death penalty scheme in light of the new aggravators, but ultimately the amendments passed both houses of the General Assembly. ${ }^{114}$

Following a minor amendment passed in 1988 regarding imposition of sentence in instances where the Pennsylvania Supreme Court overturns a death sentence on direct appellate review, ${ }^{115}$ the state legislature markedly enlarged the class of aggravating circumstances in 1989, adding aggravators (d)(13) through (d)(16) and expanding the class of persons delineated in (d)(1) whose murder would, in and of itself, be an aggravating circumstance. ${ }^{116}$ The (d)(1) class was expanded from firemen, ${ }^{117}$ peace officers, and public servants engaged in detention to add judges, the Attorney General and Deputy Attorney General, District Attorneys and Assistant District Attorneys, the Governor, Lieutenant Governor, Auditor General, and State Treasurer, and any local, state, or federal law enforcement officers, who were killed in the performance of their duties or as a result of their official positions. ${ }^{118}$ The additional aggravators provided:

circumstances that will generate a death penalty. Also in Pennsylvania we have said to the courts that if they find one aggravating circumstance and no mitigating circumstances, you have got to go to death.

The point I am making is that I believe that the addition of these two aggravating circumstances may well carry the statute beyond its constitutional limitation ....

$I d$. Representative Kukovich, who echoed the sentiments espoused by Representative O'Donnell, stated the following:

The current death penalty statute has stood [sic] the Supreme Court test of constitutional muster, but some justices have said that the Pennsylvania statute is beginning to take on a mandatory look, and by that I refer to the fact that the more items that we add to that list for which someone can receive the death penalty, the more we stretch the constitutional statute of permissibility. It might be too overlapping. Some of the various sections that would be added overlap with others. And secondly, it begins to look mandatory, and the court has held that a mandatory death penalty statute is clearly unconstitutional .... I would also point out that crimes such as voluntary manslaughter are now included, something where the intention to commit a homicide is quite different than the typical Id. murder or homicide case of a higher felony.

114. Act of July 7, 1986, No. 87, § 1, 1986 Pa. Laws 400.

115. Act of Dec. 21, 1988, No. 179, §§ 2-3, 1988 Pa. Laws 1862, 1863.

116. Act of Dec. 22, 1989, No. 99, § 2, Pa. Laws 727, 728-29.

117. The term "firemen" was substituted by "firefighters" by virtue of the Act of Mar. 15, 1995, No. 4, § 1, 1995 Pa. Laws 1st Spec. Sess. 966, 966. An amendment passed later in 1995 provided that the provisions of the statute are severable, such that if a provision thereof were to be deemed unconstitutional, other provisions that can withstand the absence of the unconstitutional section continue to operate. Act of Oct. 11, 1995, No. 22, § 1, 1995 Pa. Laws 1st Spec. Sess. 1064.

118. 42 Pa. CONS. STAT. $\S 9711(d)(1)(2003)$. 
(13) The defendant committed the killing or was an accomplice in the killing ... while in the perpetration of a felony under the provisions of the act . . known as The Controlled Substance, Drug, Device and Cosmetic Act [35 P.S. § 780-101, et seq.], and punishable under the provisions.... (relating to drug trafficking sentencing and penalties).

(14) At the time of the killing, the victim was or had been involved, associated or in competition with the defendant in the sale, manufacture, distribution or delivery of any controlled substance or counterfeit controlled substance in violation of The Controlled Substance, Drug, Device and Cosmetic Act or similar law of any other state, the District of Columbia or the United States, and the defendant committed the killing or was an accomplice to the killing . . . and the killing resulted from or was related to that association, involvement or competition to promote the defendant's activities in selling, manufacturing, distributing or delivering controlled substances or counterfeit controlled substances.

(15) At the time of the killing, the victim was or had been a nongovernmental informant or had otherwise provided any investigative, law enforcement or police agency with information concerning criminal activity and the defendant committed the killing or was an accomplice to the killing .... and the killing was in retaliation for the victim's activities as a nongovernmental informant or in providing information concerning criminal activity to an investigative, law enforcement or police agency.

(16) The victim was a child under 12 years of age. ${ }^{19}$

No member of the legislature provided an express statement indicating the rationale behind these amendments, but one can surmise that they are focused on the growing drug epidemic of the middle to late 1980s.

In 1995, the General Assembly again amended the death penalty statute to add another aggravating circumstance, $(d)(17)$, which provided that "[a]t the time of the killing, the victim was in her third trimester of pregnancy or the defendant had knowledge of the victim's pregnancy." 120 Senator Brightbill explained on the floor of the State Senate during discussion of the amendment, that he proposed the change to respond to an incident in his district where a young pregnant woman was murdered by her estranged boyfriend, who knew that the victim was pregnant. ${ }^{121}$ Senator Schwartz, the lone dissenter in the Senate, ${ }^{122}$ countered that the provision served as a means of discrimination, differentiating between the relative values of women in different situations in society. ${ }^{123}$

119. Id. § 9711(d)(13)-(16).

120. Id. § 9711(d)(17) (adopted by the Act of Nov. 17, 1995, No. 31, § 1, 1995 Pa. Laws 1st Spec. Sess. 1117, 1117).

121. 1995 Legislative JournaL-Senate 100-103 (Mar. 14, 1995) (statement of Sen. Brightbill).

122. Only one representative, Rep. Curry, voted against the proposal in the House of Representatives. 1995 Legislative JouRnAL - HouSE 542-543 (Oct. 31, 1995).

123. Id. at 100-101 (statement of Sen. Schwartz). 
Later in 1995, the legislature increased the scope of evidence that the Commonwealth could introduce during the penalty phase by allowing the jury to consider evidence of the impact the murder had on the family of the deceased victim. ${ }^{124}$ While this was not added as a specific aggravating circumstance, the General Assembly indicated that such "victim impact" evidence should be considered if and when the jury is weighing aggravating circumstances against mitigating circumstances. ${ }^{125}$ The constitutionality of this change was upheld in Commonwealth v. Means. ${ }^{126}$

Then, in 1997, the assembly again added an aggravating circumstance, this time $(d)(18)$, which provides as follows:

(18) At the time of the killing the defendant was subject to a court order restricting in any way the defendant's behavior toward the victim pursuant to $23 \mathrm{~Pa}$. C.S. [\$§ 6101, et seq.] (relating to protection from abuse) or any other order of a court of common pleas or of the minor judiciary designed in whole or in part to protect the victim from the defendant. ${ }^{127}$

The amendment was introduced by Representative Fichter in the House "in the wake of the murders of two young women in [his] district allegedly at the hands of the men against whom they had filed a protection-from-abuse order. While this legislation may come too late to protect [those victims], perhaps we can prevent other unnecessary deaths." 128

On several occasions, the General Assembly has amended the death penalty statute as it relates to the review that the Pennsylvania Supreme Court conducts in all death penalty cases. ${ }^{129}$ Interestingly, however, the legislature

124. 42 Pa. Cons. Stat. § 9711(a)(2) (2003) (adopted by the Act of October 11, 1995, No. 22, § 1, 1995 Pa. Laws 1064, 1064); see also 42 PA. CONS. STAT. § 9738 (2003) (governing victim impact statements).

125. Section 9711(c)(2) (adopted by the Act of Oct. 11, 1995, No. 22, § 1, 1995 Pa. Laws 1064 1st Spec. Sess. 1064, 1064).

126. Commonwealth v. Means, 773 A.2d 143, 158-59 (Pa. 2001).

127. Section 9711(d)(18) (adopted by the Act of Apr. 25, 1997, No. 6, § 1, 1997 Pa. Laws 84, 84).

128. 1997 Legislative JournaL-House 166 (Feb. 11, 1997) (statement of Rep. Fichter).

129. See Act of July 7, 1986, No. 87, § 1, 1986 Pa. Laws 400; Act of June 25, 1997, No. 28, § 1, 1997 $\mathrm{Pa}$. Laws 293 (removing proportionality review from the death penalty statute). This legislation was made possible by Pulley v. Harris, 465 U.S. 37, 51 (1984), where the United States Supreme Court held that the Eighth Amendment to the United States Constitution, as applied to the states through the Fourteenth Amendment, does not mandate that a state death penalty statute provide for proportionality review. Id.; see also Commonwealth v. Gribble, 703 A.2d 426, 439 (Pa. 1997), cert. denied, 525 U.S. 1005 (1998). In Gribble, the Pennsylvania Supreme Court reasoned:

Notwithstanding the Court's pronouncement in Pulley, the General Assembly, through 42 Pa. C.S. $\S 9711(\mathrm{~h})(3)(\mathrm{iii})$, has, until recently, continued to require this Court to conduct a proportionality review in each case where a sentence of death had been imposed. 
has not expanded the breadth or scope of the mitigating circumstances or evidence that a defendant can present in support of a sentence of life imprisonment.

\section{StatisticAl StUdy}

It is apparent from our research that the class of conduct for which capital punishment is imposable in the Commonwealth of Pennsylvania has historically taken on an hourglass-like shape as illustrated in Figure 1. To elaborate, with the exception of William Penn's Great Law, capital punishment was originally required for a multitude of crimes that were whittled to one by 1794. Later, the legislature abolished mandatory imposition of the death penalty in favor of allowing the jury to exercise its discretion in setting the punishment (life imprisonment or death). Since 1925, however, the General Assembly has added a crime to the list of those that are death-eligible and has, numerous times, increased the number of aggravating factors that the factfinder can consider when exercising its discretion in setting the penalty.

Then, on June 25, 1997, the Governor signed legislation that removes proportionality review from the death penalty statute by deleting all of subsection (h)(3)(iii) and the part of subsection (h)(4) that references proportionality review. Act of June 25, 1997, No. 28, § 1 (Act 28). Section 3 of Act 28 states that "[t]his act shall take effect immediately." Id. 
Figure 1-Historical Representation of Pennsylvania Capital Punishment Legislation

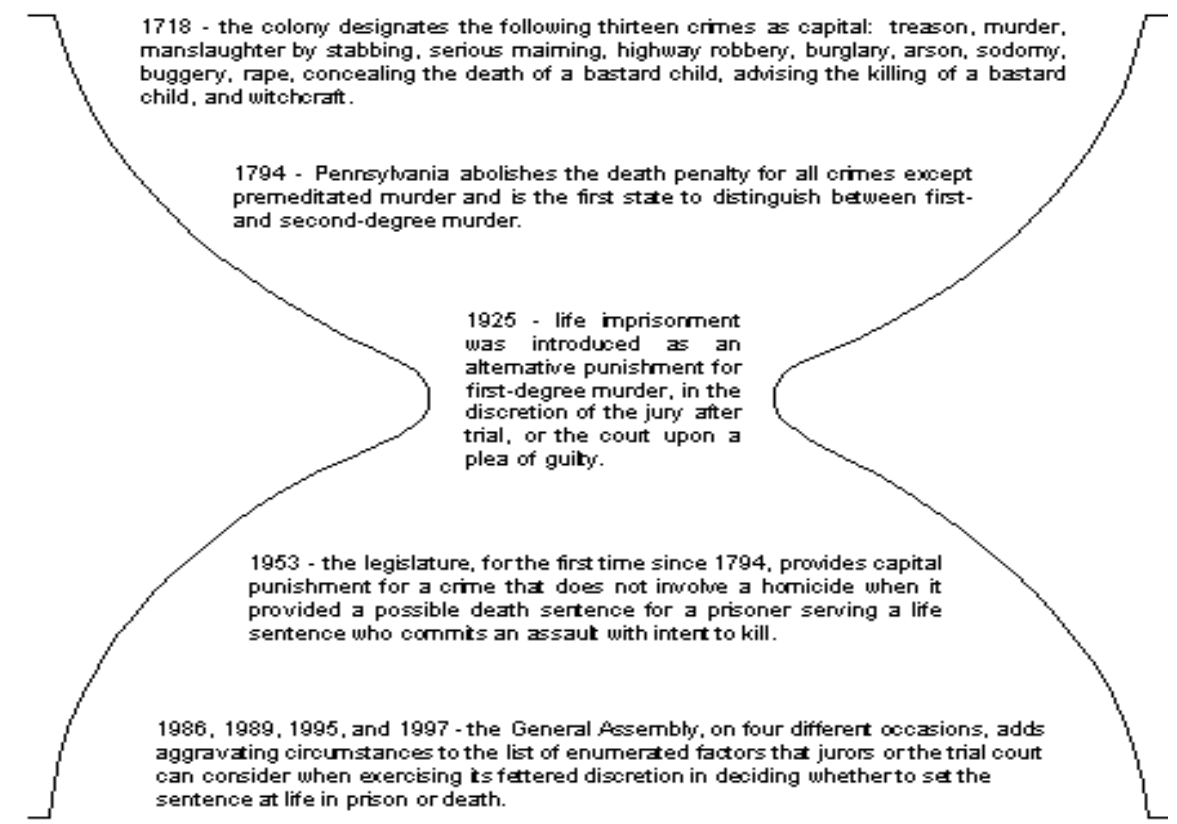

We found fascinating that the legislation of the late eighteenth, nineteenth, and early twentieth centuries consistently restricted the imposition of capital punishment, but that the legislature had seemingly reversed course over the last fifty years. Accordingly, we endeavored to analyze whether the recent statutory additions of aggravating circumstances had any effect on imposition of death sentences, as feared by some legislators. Before proceeding to the data, however, a few words of limitation are in order about the statistical universe from which we are operating.

\section{A. Data Methods}

The Supreme Court of Pennsylvania, by Order dated December 6, 1983, directed the President Judges in each county of the Commonwealth to complete a statistical review form in all cases where the defendant was convicted of first-degree murder and forward those forms to the Administrative Office of Pennsylvania Courts (AOPC) in order to comply with the proportionality review mandated by the death penalty statute. The Order further directed that the President Judges comply with the dictate retroactively 
to September 13, 1978. Thereafter, in Commonwealth v. Frey, ${ }^{130}$ the Supreme Court of Pennsylvania instructed the President Judges to provide that information to AOPC on an ongoing basis. ${ }^{131}$ The December 6th Order and Frey continued in full effect until June 25, 1997, ${ }^{132}$ when the Governor of Pennsylvania signed into law legislation removing proportionality review from Section 9711, thereby obviating the need for AOPC to continue to maintain statistics in first-degree murder cases. ${ }^{133}$ The AOPC database contains records of first-degree murder convictions from 1978 until the present.

Pursuant to the December 6, 1983 Order of the Supreme Court of Pennsylvania, judges were required to recreate data sheets for first-degree murder convictions from September 13, 1978, through December 6, 1983. We recognize that data collection and reporting is a task much easier to complete when done at the time of the event about which the data is being collected and reported. ${ }^{134}$ We have, nonetheless decided to use this data because we have found no objective evidence that the data are in any way flawed or inaccurate.

Conversely, the information from June 25, 1997, until the present is incomplete because, with the abrogation of proportionality review as of that date, trial court judges are no longer required to complete first-degree murder conviction statistical forms. Many judges have continued to fill out the forms, and the President Judges of the counties have forwarded whatever data they have collected to AOPC, so AOPC has maintained its database. We cannot readily ascertain what percentage of cases from 1997 to the present are reflected in the data and, indeed, our cursory review of the information provided by AOPC reveals that the sample of cases sent to AOPC over the last six years is not necessarily a fair representation of the universe of cases actually heard over that period. We have made this determination because the Commonwealth sought the death penalty in less than one-third of the cases for which we have the records, where the offense was committed after June 25, 1997; whereas in the three years preceding the June 25, 1997 legislation, the

130. Commonwealth v. Frey, 475 A.2d 700 (Pa. 1984), cert. denied, 469 U.S. 963 (1984).

131. Id. at 707.

132. Act of June 25, 1997, No. 28, § 1, 1997 Pa. Laws 293 (effective immediately).

133. See also Gribble, 703 A.2d at $438-41$ (holding that the abrogation of proportionality review cannot operate retroactively; defendants convicted before June 25, 1997, have a right to the review mandated at that time).

134. For a more in-depth discussion of data problems inherent during this period, see Leigh B. Bienen, Criminal Law: The Proportionality Review of Capital Cases by State High Courts After Gregg: Only "The Appearance of Justice"?, 87 J. CRIM. L. \& CRIMINOLOGY 130, 163-64 (1996); John F. Karns \& Lee S. Weinberg, The Death Sentence in Pennsylvania-1978-1990: A Preliminary Analysis of the Effects of Statutory and Nonstatutory Factors, 95 DICK. L. REV. 691, 696-98 (1991). 
Commonwealth sought the death penalty in $53 \%$ of cases. ${ }^{135}$ Accordingly, we have limited our study to the database records where the offense was committed prior to June 25, 1997. Therefore, we have similarly limited our statistical consideration of aggravating circumstances to those enacted prior to this date, specifically, aggravating circumstances one through sixteen. ${ }^{136}$

As of March 25, 2003, the AOPC database contained 2,630 records. We removed sixty-eight records pursuant to the preceding paragraph, leaving 2,562 cases. Reviewing each remaining record for internal inconsistencies, we determined that 156 of these records, or approximately $6.1 \%$, were corrupted in some way. Specifically, in sixty cases, the database indicated that the Commonwealth did not seek the death penalty but did present aggravating circumstances. This is not possible because in cases where the Commonwealth does not seek the death penalty, there is no sentencing hearing. In an additional ninety-six cases, the database reflects that the Commonwealth sought the death penalty but did not present any aggravating circumstances. This is also impossible because a sentencing hearing is convened only when the Commonwealth can and does present the existence of aggravating circumstances. While we could conceivably correct some of the information in these 156 cases by referencing opinions published in those of the cases that were appealed to the superior court or Supreme Court of Pennsylvania, to do so would corrupt the data. Specifically, such corrections would create a bias within the corrected cases towards those where the Commonwealth was successful in seeking the death penalty, as the Supreme Court of Pennsylvania is required to publish an opinion in all cases in which the trial court sentences a defendant to death. ${ }^{137}$ Accordingly, we have removed these additional 156 records from our consideration entirely, leaving us with a statistical universe of 2,406 database entries.

At this point, it is important to note the methods and limitations of our statistical analysis. When attempting to derive meaningful statistics regarding some of our tests, we ran into the problem of insufficient sample sizes. Simply put, there are not enough cases involved in some of our tables to make them meaningful. We have attempted to discuss and draw conclusions from data that is of true statistical significance and, correspondingly, we have refrained

135. We tested the data to see if the percentages of cases were similar in both periods by the following factors: gender, race, geography, and whether the Commonwealth sought the death penalty. The results of our analysis indicate that the percentages were relatively uniform in the two periods except when we tested for the last variable.

136. See 42 PA. CONS. STAT. § 9711(d)(1)-(16) (2003).

137. See id. §9711(i). 
from the discussion of data that seems significant on its face but where the sheer lack of numbers makes it unreliable. As a result, most tables that we present include both the standard deviation as well as the commonly accepted confidence interval of $95 \% .{ }^{138}$ Thus, the reader will have full knowledge of the efficacy of our tests and be able to discern that which is truly meaningful. Furthermore, in any statistical analysis, it is clear that there may be factors at play that bias or skew the numbers. Accordingly, we have tested for bias where possible or simplified our tests and tables to eliminate bias. To the extent possible, we will discuss what unaccountable or immeasurable factors may affect our data.

\section{B. Data Analysis}

Keeping in mind our observation and the concerns expressed by some legislators that, with the recent increase in the number of aggravating circumstances in the death penalty statute, the death sentence is taking on a more mandatory nature, ${ }^{139}$ we decided to analyze the data for any correlation between the passage of time, as measured by the number of aggravating circumstances available, and the imposition of capital punishment.

To engage in this study, we grouped the data into periods, so as to identify the number of aggravating circumstances actually available for each case. This posed some problems because, while as a general rule, aggravating circumstances would only be available for the Commonwealth to pursue if the offense occurred after the date those aggravators were added to the statute, ${ }^{140}$ the Pennsylvania Supreme Court has explained that this rule has exceptions. ${ }^{141}$ Specifically, if an aggravating circumstance is enacted after the date of the offense but, under the circumstances of the case, the newly enacted aggravating circumstance is similar in substance to an aggravating

138. A $95 \%$ confidence interval indicates that, with repeated sampling, there is a $95 \%$ chance that any other sample mean obtained will fall within the range. In other words, if a statistical finding is $50.00 \% \pm$ $10.00 \%$, that means that, if one used data sets with similar characteristics, in $95 \%$ of those data sets, the sample mean would be between $40.00 \%$ and $60.00 \%$. Therefore, the smaller the range, the more precise the result is.

139. See supra note 110.

140. In the vein of prohibiting ex post facto laws, the general rule is that aggravating circumstances can only be pursued by the Commonwealth if the aggravator was "on the books" at the time of the offense. Commonwealth v. Fisher, 741 A.2d 1234, 1238 (Pa. 1999), cert. denied, 531 U.S. 829 (2000).

141. See Fisher, 741 A.2d at 1238-41; Commonwealth v. Zook, 615 A.2d 1, 21-22 (Pa. 1992), cert. denied, 507 U.S. 974 (1993). 
circumstance that existed at the time of the offense, the Commonwealth can pursue the newly enacted aggravating circumstance. ${ }^{142}$

In light of these principles, records belonging to Offense Period 1 are those where the crime occurred prior to September 5, 1986. During Offense Period 1, the first ten aggravating circumstances were available for the Commonwealth to pursue. Offense Period 2 encompasses crimes committed from September 5, 1986, until December 21, 1989, for which the Commonwealth could pursue any of the first twelve aggravating circumstances. Offense Period 3 begins with crimes committed on or after December 22, 1989, and continuing until the abrogation of proportionality review on June $25,1997 .{ }^{143}$ The Commonwealth could pursue any of the first sixteen aggravating circumstances throughout Offense Period 3. We have excluded the aggravating circumstances presented and found that they were generally not available during the Offense Period so that we can arrive at a more accurate picture of the events and the actions of the Commonwealth, the defense, and the sentencing body during each of these stages. ${ }^{144}$

142. Fisher, 741 A.2d at 1238-41; Zook, 615 A.2d at 21-22. In Zook, the Pennsylvania Supreme Court determined that aggravator (d)(10) - commission of a prior or contemporaneous offense for which a sentence of life imprisonment or death was available — was substantially similar to (d)(11) - commission of a prior or contemporaneous murder. Zook, 615 A.2d at 21. In Fisher, the Court held that, pursuant to the facts of that case, the $(\mathrm{d})(15)$ aggravator - the victim had provided investigative, law enforcement, or police agencies with information concerning criminal activity — was substantially similar to (d)(5) - the victim was killed for the purpose of preventing his or her testimony against the defendant in any grand jury or criminal proceeding involving those crimes. Fisher, 741 A.2d at 1239.

143. See supra note 128. We note that aggravator seventeen (the victim was in her third trimester of pregnancy) was added to the statute on November 17, 1995, and that aggravator eighteen (at the time of the killing, the defendant was under court order restricting the defendant's contact with the victim) was added on April 25, 1997. See supra, notes 119 and 127. Because these aggravating circumstances were added to the AOPC Database in close temporal proximity to the abrogation of proportionality review, the AOPC never added these aggravators to the database and, accordingly, we have no information on their use.

144. In Offense Period 1, the Commonwealth sought the death penalty 462 times and on twenty-one occasions presented aggravating circumstances eleven through sixteen. In fourteen cases, the sentencing body found the existence of the subsequently added aggravating circumstance. In Offense Period 2, the Commonwealth sought aggravating circumstances fifteen and sixteen two times, but the sentencing body did not find either of these aggravators. 
Table 1-Incidence of Death Penalty Based on Number of Aggravating Circumstances Found

\begin{tabular}{|cccccr|}
\hline $\begin{array}{c}\text { Number of } \\
\text { Aggravating } \\
\begin{array}{c}\text { Circumstances } \\
\text { Found }\end{array}\end{array}$ & $\begin{array}{c}\text { Death } \\
\text { Penalty }\end{array}$ & $\begin{array}{c}\text { Life } \\
\text { Imprisonment }\end{array}$ & $\begin{array}{r}\text { Total } \\
\text { which } \\
\text { Death } \\
\text { Penalty is } \\
\text { Imposed }\end{array}$ & $\begin{array}{r}\text { 95\% Confidence } \\
\text { Interval }\end{array}$ \\
\hline 0 & 0 & 480 & 480 & $\mathbf{0 . 0 0 \%}$ & N/A \\
\hline 1 & 158 & 200 & 358 & $\mathbf{4 4 . 1 3 \%}$ & $\begin{array}{r}44.13 \% \pm \\
5.15 \%\end{array}$ \\
\hline 2 & 168 & 70 & 238 & $\mathbf{7 0 . 5 9 \%}$ & $\begin{array}{r}70.59 \% \pm \\
5.80 \%\end{array}$ \\
\hline 3 & 72 & 13 & 85 & $\mathbf{8 4 . 7 1 \%}$ & $\begin{array}{r}84.71 \% \pm \\
7.82 \%\end{array}$ \\
\hline 4 & 17 & 3 & 20 & $\mathbf{8 5 . 0 0 \%}$ & $\begin{array}{r}85.00 \% \pm \\
17.12 \%\end{array}$ \\
\hline 5 & 5 & 0 & 5 & $\mathbf{1 0 0 . 0 0 \%}$ & $\mathrm{N} / \mathrm{A}$ \\
\hline Total & $\mathbf{4 2 0}$ & $\mathbf{7 6 6}$ & $\mathbf{1 1 8 6}$ & $\mathbf{3 5 . 4 1 \%}$ & $\begin{array}{r}\mathbf{3 5 . 4 1 \%} \% \\
\mathbf{2 . 7 2 \%}\end{array}$ \\
\hline
\end{tabular}

As articulated earlier, our intention when we began this study was to ascertain whether the fears of some of the members of the Pennsylvania General Assembly, that the death penalty statute was making death sentences more mandatory with the addition of aggravating circumstances without concomitant increases in allowable mitigation evidence, were well founded. To test this general theory, we developed one hypothesis and four basic questions. As a matter of foundation, we hypothesized that there is a positive correlation between the number of aggravating circumstances found by the sentencing body and the imposition of a death sentence.

Table 1 illustrates that, in fact, there is a clear positive correlation. We can state, with near absolute certainty, that as the sentencing body finds a greater number of aggravating circumstances, the death sentence is imposed 
at an increasing rate. This effect is particularly striking when the sentencing body moves from zero to one aggravating circumstance found $(0 \%$ death, by statutory fiat, to $44.13 \%)^{145}$ and from one to two aggravators found (the imposition of the death penalty rises from $44.13 \%$ to $70.59 \%$ ). While not much can be said with confidence about the data compiled where the sentencing body finds four or five aggravating circumstances, the data for these periods comports with the overall trend that the more aggravating circumstances found by the jury or trial court, the more likely that the entity imposing sentence will choose death.

Table 2-Incidence of the Commonwealth Seeking the Death Penalty by Offense Period for All First-Degree Murder Cases

\begin{tabular}{|ccccccc|}
\hline $\begin{array}{c}\text { Offense } \\
\text { Period }\end{array}$ & $\begin{array}{c}\text { Death } \\
\text { Penalty } \\
\text { Sought }\end{array}$ & $\begin{array}{c}\text { Death } \\
\text { Penalty } \\
\text { Sought }\end{array}$ & Total & $\begin{array}{c}\text { \% for which } \\
\text { Death } \\
\text { Penalty is } \\
\text { Sought }\end{array}$ & $\begin{array}{c}\text { Standard } \\
\text { Deviation }\end{array}$ & $\begin{array}{c}95 \% \\
\text { Confidence } \\
\text { Interval }\end{array}$ \\
\hline $\begin{array}{r}\text { To 9/5/86 } \\
\text { (Period 1) }\end{array}$ & 462 & 527 & 989 & $\mathbf{4 6 . 7 1 \%}$ & 0.4992 & $\begin{array}{r}46.71 \% \pm \\
3.11 \%\end{array}$ \\
\hline $\begin{array}{c}9 / 5 / 86- \\
12 / 21 / 89\end{array}$ & 234 & 242 & 476 & $\mathbf{4 9 . 1 6 \%}$ & 0.5005 & $\begin{array}{r}49.16 \% \pm \\
4.50 \%\end{array}$ \\
$($ Period 2$)$ & & & & & & \\
\hline $\begin{array}{c}12 / 21 / 89 \\
-6 / 25 / 97 \\
(\text { Period 3) }\end{array}$ & 482 & 432 & 914 & $\mathbf{5 2 . 7 4 \%}$ & 0.4995 & $\begin{array}{r}52.74 \% \pm \\
3.24 \%\end{array}$ \\
\hline $\begin{array}{c}\text { Date } \\
\text { Unknown }\end{array}$ & 8 & 19 & 27 & $\mathbf{2 9 . 6 3 \%}$ & 0.4653 & $\begin{array}{r}29.63 \% \pm \\
18.45 \%\end{array}$ \\
\hline Total & $\mathbf{1 1 8 6}$ & $\mathbf{1 2 2 0}$ & $\mathbf{2 4 0 6}$ & $\mathbf{4 9 . 2 9 \%}$ & $\mathbf{0 . 5 0 0 1}$ & $\begin{array}{r}\mathbf{4 9 . 2 9 \%} \\
\mathbf{2 . 0 0 \%}\end{array}$ \\
\hline
\end{tabular}

145. When referring to statistics in the body of the text, we will generally refer to the sample mean without referencing the confidence interval, though we will provide the $95 \%$ confidence interval in tabular form. 
The finding that the death penalty is imposed more frequently as the sentencing body finds more aggravating circumstances led to our four basic questions concerning the increased number of aggravators available to the Commonwealth over time. Specifically, we wanted to test: (1) whether the Commonwealth seeks the death penalty more often as the legislature makes more aggravating circumstances available; (2) whether the Commonwealth presents more aggravating circumstances as the legislature makes more aggravating circumstances available; (3) whether the sentencing body finds more aggravating circumstances as the legislature makes more aggravating circumstances available; and (4) whether the sentencing body imposes the death penalty more often as the legislature makes more aggravating circumstances available.

Whether the Commonwealth has been seeking the death penalty more often with the addition of aggravating circumstances is simply a function of the Commonwealth's reaction to the legislature and, as Table 2 indicates, the Commonwealth has been seeking the death penalty slightly more often as time has progressed. During Offense Period 1, the Commonwealth sought the death penalty in $46.71 \%$ of cases in which the defendant was convicted of firstdegree murder. While the data for Offense Period 2 signifies an increase to $49.16 \%$, we cannot say with confidence that this increase is actually present because the confidence intervals overlap. ${ }^{146}$ It is, however, an indication of an upward trend, one that is strengthened by the more significant increase from Offense Period 1 to Offense Period 3. Thus, the tendency toward seeking the death penalty increases as more aggravating circumstances become available and, consequently, so does the chance that the General Assembly has created a more mandatory statutory scheme.

146. An overlap in confidence intervals indicates that the upper end of the range of the lower sample mean falls within the range for the higher sample mean. For example, a $50.00 \% \pm 10.00 \%$ statistic overlaps confidence intervals with a $31.16 \% \pm 9.00 \%$ statistic because the range of $40.00 \%-40.16 \%$ is in both confidence intervals. 
Table 3-Average Number of Aggravators Presented by the Commonwealth When Seeking the Death Penalty by Offense Period

\begin{tabular}{|ccccc|}
\hline $\begin{array}{c}\text { Offense } \\
\text { Period }\end{array}$ & $\begin{array}{c}\text { Number of } \\
\text { Cases }\end{array}$ & $\begin{array}{c}\text { Average } \\
\text { Number of } \\
\text { Aggravators } \\
\text { Presented }\end{array}$ & $\begin{array}{c}\text { Standard } \\
\text { Deviation }\end{array}$ & $\begin{array}{c}95 \% \\
\text { Confidence } \\
\text { Interval }\end{array}$ \\
\hline $\begin{array}{c}\text { To 9/5/86 } \\
\text { (Period 1) }\end{array}$ & 462 & $\mathbf{1 . 9 9 5 7}$ & 1.3140 & $\begin{array}{r}1.9957 \pm \\
0.1198\end{array}$ \\
\hline $\begin{array}{c}9 / 5 / 86- \\
12 / 21 / 89 \\
(\text { Period 2) }\end{array}$ & 234 & $\mathbf{1 . 7 2 6 5}$ & 0.8604 & $\begin{array}{r}1.7265 \pm \\
0.1102\end{array}$ \\
\hline $\begin{array}{c}12 / 21 / 89- \\
6 / 25 / 97 \\
(\text { Period 3) }\end{array}$ & 482 & $\mathbf{1 . 9 4 1 9}$ & 0.9719 & $\begin{array}{r}1.9419 \pm \\
0.0868\end{array}$ \\
\hline $\begin{array}{c}\text { Date } \\
\text { Unknown }\end{array}$ & 8 & $\mathbf{1 . 3 7 5 0}$ & 0.5175 & $\begin{array}{r}1.3750 \pm \\
0.4318\end{array}$ \\
\hline Total & $\mathbf{1 1 8 6}$ & $\mathbf{1 . 9 1 6 5}$ & $\mathbf{1 . 1 0 1 9}$ & $\mathbf{1 . 9 1 6 5 \pm}$ \\
\hline
\end{tabular}

Having determined that the Commonwealth has been seeking the death penalty more often as the legislature has added more aggravating circumstances, we next proceeded to understand how the Commonwealth presents aggravating factors to the sentencing body. Specifically, we wondered whether, with the addition of available aggravating circumstances over time, the Commonwealth is presenting a greater number of aggravators in an average case, or, alternatively, whether the addition of factors simply leads the Commonwealth to pursue the death penalty in a broader range of cases. As illustrated by Tables 3 and 4, we found the second of these propositions to be the more likely scenario. In fact, Table 3 shows that the number of aggravators presented decreased markedly from Offense Period 1 to Offense Period 2 and decreased, albeit within the confidence interval range, from Offense Period 1 to Offense Period 3. We recognize a slight increase in the average number of aggravating circumstances presented from Offense Period 2 to Offense Period 3; that does not refute the conclusion, however, 
that, over the gamut of time covered, the Commonwealth has not presented more aggravators on a case-by-case basis.

We next began to analyze whether the Commonwealth is using the additional aggravating circumstances to present more aggravating circumstances in the cases for which it would have sought the death penalty without the newly added aggravators and/or whether the Commonwealth is using newly created aggravating circumstances (eleven through sixteen) to seek the death penalty more often. To accomplish this, we categorized the 716 cases in Offense Periods 2 and 3 based on whether the Commonwealth presented: (1) only newly-enacted aggravators; (2) only the original ten aggravators; or (3) both. The figures are represented in Table 4.

There were 653 cases during Offense Periods 2 and 3 where the Commonwealth presented at least one of the original ten aggravating circumstances. In those cases, the Commonwealth presented an average of 1.9357 aggravators. However, in the 462 cases during Offense Period 1, during which only the original ten aggravators were available, the Commonwealth presented, on average, 1.9957 aggravating circumstances. Interestingly, this suggests that the Commonwealth, overall, is seeking less of the potentially presentable aggravators per case. This finding lessens to some degree the fear that the increased availability of aggravators leads to a more mandatory death penalty based on the conduct of the Commonwealth in deciding how many aggravating circumstances to seek. ${ }^{147}$ We know that this could be the result of various factors, including, but not limited to: (1) changing societal views on the death penalty; (2) varying in philosophies of different District Attorney's Offices; and (3) the Commonwealth's abandonment of weaker aggravating circumstances that they would have presented in Offense Period 1 in favor of the newly enacted, and possibly more applicable, aggravators enacted later. On the whole, however, it seems clear that the addition of aggravating circumstances has not led the Commonwealth to present more aggravators.

147. It is impossible to dispel entirely this fear because the Commonwealth retains the discretion to not present aggravating circumstances that would conceivably be available. 
Table 4-Aggravators Presented and Found During Offense Periods 2 and 3 Dependent Upon Whether the Aggravators Presented Were Originally Included in the Statutory Scheme

\begin{tabular}{|ccccccc|}
\hline $\begin{array}{c}\text { Which } \\
\text { Aggravators } \\
\text { Found }\end{array}$ & Cases & $\begin{array}{c}\text { Average } \\
\text { Aggravators } \\
\text { Presented }\end{array}$ & $\begin{array}{c}\text { Death } \\
\text { Penalty } \\
\text { Imposed }\end{array}$ & $\begin{array}{c}\% \\
\text { Death } \\
\text { Penalty } \\
\text { Imposed }\end{array}$ & $\begin{array}{c}\text { Average } \\
\text { Aggravators } \\
\text { Found }\end{array}$ & $\begin{array}{c}\text { Aggravators } \\
\text { Found of } \\
\text { Presented }\end{array}$ \\
\hline $\begin{array}{c}\text { Aggravators } \\
11-16 \text { Only }\end{array}$ & 63 & $\mathbf{1 . 2 0 6 3}$ & 31 & $49.21 \%$ & 0.8889 & $73.68 \%$ \\
\hline $\begin{array}{c}\text { Aggravators } \\
1-10 \text { and } \\
11-16\end{array}$ & 206 & $\mathbf{2 . 7 7 1 8}$ & 87 & $42.23 \%$ & 1.5388 & $55.52 \%$ \\
\hline $\begin{array}{c}\text { Aggravators } \\
1-10 \text { Only }\end{array}$ & 447 & $\mathbf{1 . 5 5 0 3}$ & 109 & $24.38 \%$ & 0.7562 & $48.77 \%$ \\
\hline $\begin{array}{c}\text { All Cases } \\
\text { Except } \\
11-16 \text { Only }\end{array}$ & 653 & $\mathbf{1 . 9 3 5 7}$ & 196 & $30.02 \%$ & 1.0031 & $51.82 \%$ \\
\hline $\begin{array}{c}\text { All Cases } \\
\text { During } \\
\text { Periods } 2 \\
\text { and 3 }\end{array}$ & 716 & $\mathbf{1 . 8 7 1 5}$ & 227 & $31.70 \%$ & 0.9930 & $53.06 \%$ \\
\hline
\end{tabular}


Table 5-Average Number of Aggravators Presented by the Sentencing Body When the Commonwealth Seeks the Death Penalty by Offense Period

\begin{tabular}{|ccccc|}
\hline $\begin{array}{c}\text { Offense } \\
\text { Period }\end{array}$ & Number of Cases & $\begin{array}{c}\text { Average Number } \\
\text { of Aggravators } \\
\text { Presented }\end{array}$ & $\begin{array}{c}\text { Standard } \\
\text { Deviation }\end{array}$ & $\begin{array}{c}\text { Confidence } \\
\text { Interval }\end{array}$ \\
\hline $\begin{array}{c}\text { To 9/5/86 } \\
\text { (Period 1) }\end{array}$ & 462 & $\mathbf{1 . 0 0 4 3}$ & 1.0954 & $1.0043 \pm 0.0999$ \\
\hline $\begin{array}{c}\text { 9/5/86 - } \\
12 / 21 / 89 \\
(\text { Period 2) }\end{array}$ & 234 & $\mathbf{0 . 9 9 5 7}$ & 0.9957 & $0.9957 \pm 0.1276$ \\
\hline $\begin{array}{c}12 / 21 / 89- \\
6 / 25 / 97 \\
(\text { Period 3) }\end{array}$ & 482 & $\mathbf{0 . 9 9 1 7}$ & 1.0457 & $0.9917 \pm 0.0934$ \\
\hline $\begin{array}{c}\text { Date } \\
\text { Unknown }\end{array}$ & 8 & $\mathbf{0 . 1 2 5 0}$ & 0.3536 & $0.1250 \pm 0.2950$ \\
\hline Total & $\mathbf{1 1 8 6}$ & $\mathbf{1 . 0 0 6 7}$ & $\mathbf{1 . 0 5 4 6}$ & $\mathbf{1 . 0 0 6 7 \pm \mathbf { 0 . 0 6 0 0 }}$ \\
\hline
\end{tabular}

Also of note were sixty-three cases in Offense Periods 2 and 3 whence the Commonwealth presented only newly-enacted aggravating circumstances. This accounts for $8.80 \%$ of all cases in which the Commonwealth sought the death penalty during these periods and likely results in much of the increase in the incidence of the Commonwealth seeking the death penalty presented in Table 2.

It is only natural that, after considering the average number of aggravating circumstances presented by the Commonwealth, we contemplate the average number of aggravators found by the sentencing body. Based on the statistics reflected in Table 5, there is no increase in the number of aggravating circumstances found by the sentencing body over time. While the sample mean shows a very slight decrease, when taking into account the confidence interval, we cannot say that this decrease has any statistical significance. Accordingly, the sentencing body finds the existence of, on average, approximately one aggravating circumstance in each case, regardless of the number of aggravating circumstances available. Likewise, when considering Tables 3 and 5 in concert, with a possible slight deviation in Offense Period 
2 , the percentage of aggravators found out of aggravators presented remains constant. ${ }^{148}$

Table 6-Incidence of the Commonwealth Successfully Seeking the Death Penalty by Offense Period

\begin{tabular}{|c|c|c|c|c|c|c|}
\hline $\begin{array}{l}\text { Offense } \\
\text { Period }\end{array}$ & $\begin{array}{l}\text { Death } \\
\text { Penalty } \\
\text { Sought }\end{array}$ & $\begin{array}{c}\text { Life } \\
\text { Imprisonment }\end{array}$ & $\begin{array}{c}\text { Death } \\
\text { Penalty } \\
\text { Imposed }\end{array}$ & $\begin{array}{c}\% \\
\text { Death } \\
\text { Penalty } \\
\text { When } \\
\text { Sought }\end{array}$ & $\begin{array}{l}\text { Standard } \\
\text { Deviation }\end{array}$ & $\begin{array}{c}95 \% \\
\text { Confidence } \\
\text { Interval }\end{array}$ \\
\hline $\begin{array}{l}\text { To } 9 / 5 / 86 \\
(\text { Period } 1)\end{array}$ & 462 & 269 & 193 & $41.77 \%$ & 0.4937 & $\begin{array}{r}41.77 \% \pm \\
4.50 \%\end{array}$ \\
\hline $\begin{array}{c}9 / 5 / 86- \\
12 / 21 / 89 \\
(\text { Period } 2)\end{array}$ & 234 & 149 & 85 & $36.32 \%$ & 0.4820 & $\begin{array}{r}36.32 \% \pm \\
6.18 \%\end{array}$ \\
\hline $\begin{array}{c}12 / 21 / 89- \\
6 / 25 / 97 \\
(\text { Period } 3)\end{array}$ & 482 & 340 & 142 & $29.46 \%$ & 0.4563 & $\begin{array}{r}29.46 \% \pm \\
4.07 \%\end{array}$ \\
\hline $\begin{array}{c}\text { Date } \\
\text { Unknown }\end{array}$ & 8 & 8 & 0 & $0.00 \%$ & 0.0000 & N/A \\
\hline Total & 1186 & 766 & 420 & $35.41 \%$ & 0.4785 & $\begin{array}{r}35.41 \% \pm \\
2.72 \%\end{array}$ \\
\hline
\end{tabular}

The final step of this analysis centers on the success of the Commonwealth when seeking the death penalty. As portrayed in Table 6, with the progression of time, and the concomitant increase in the number of aggravating circumstances available, the sentencing body is imposing the death penalty less often. In Offense Period 1, when the Commonwealth sought

148. During Offense Period 1, the sentencing body found $52.08 \%$ of aggravators that the Commonwealth presented. During Offense Period 2, the sentencing body found $57.67 \%$ of aggravators that the Commonwealth presented. During Offense Period 3, the sentencing body found $51.07 \%$ of aggravators that the Commonwealth presented. Overall, the sentencing body found $52.53 \%$ of aggravators that the Commonwealth presented. 
the death penalty, the sentencing body concurred approximately $42 \%$ of the time. In Offense Period 2, that figure dropped to $36 \%$, and during Offense Period 3, the Commonwealth was only successful in seeking the death penalty in $29 \%$ of cases. Taking into account confidence intervals, the drop from Offense Period 1 to Offense Period 3 ranges from almost $10 \%$ to close to $45 \%$.

Figure 2 illustrates the ultimate disposition of all first-degree murder cases by offense period. There were 989 first-degree murder convictions in Offense Period 1. During that span, the Commonwealth did not seek the death penalty in 527 cases, was unsuccessful in seeking capital punishment in 269 cases, and, in 193 cases, the sentencing body imposed a death sentence. Therefore, during Offense Period 1, the sentence of death was imposed in only $19.51 \%$ of cases where the defendant was convicted of first-degree murder.

Correspondingly, there were 476 first-degree murder convictions during Offense Period 2. The Commonwealth did not seek the death penalty in 242 cases, was unsuccessful in seeking capital punishment in 149 cases, and, in 85 cases, the sentencing body imposed a death sentence. Therefore, during Offense Period 2, the sentence of death was imposed in only $17.86 \%$ of cases where the defendant was convicted of first-degree murder (a drop of approximately $8.5 \%$ ). Finally, there were 914 first-degree murder convictions in Offense Period 3. The Commonwealth did not seek the death penalty in 432 cases, was unsuccessful in seeking capital punishment in 340 cases, and, in 142 cases, the sentencing body imposed a death sentence. Therefore, during Offense Period 3, the sentence of death was imposed in only $15.54 \%$ of cases where the defendant was convicted of first-degree murder (a drop of approximately $13.0 \%$ from Offense Period 2 and $20.3 \%$ from Offense Period 1).

As evident, Figure 2 shows an increase in the percentage of cases where the Commonwealth sought the death penalty (the black and white sections) and a corresponding decrease in the percentage of cases where the Commonwealth successfully sought the death penalty (the white section only). Clearly, the Commonwealth is seeking the death penalty more often. What is more interesting, however, is that not only is the sentencing body sentencing a first-degree murder convict to death in a smaller percentage of cases where the Commonwealth actually seeks the death penalty but, in fact, is imposing a sentence of death in a smaller percentage of all first-degree murder cases, irrespective of whether the Commonwealth actually seeks the death penalty. Therefore, the increase in the number of aggravating circumstances promulgated by the General Assembly has not led, as some have feared, to a more mandatory death penalty; in fact, it appears that, if anything, the legislature has created new aggravating circumstances in the hope of stemming 
the apparent tide away from sentencing those convicted of first-degree murder to death.

Figure 2-Disposition of First-Degree Murder Cases by Offense Period ${ }^{149}$

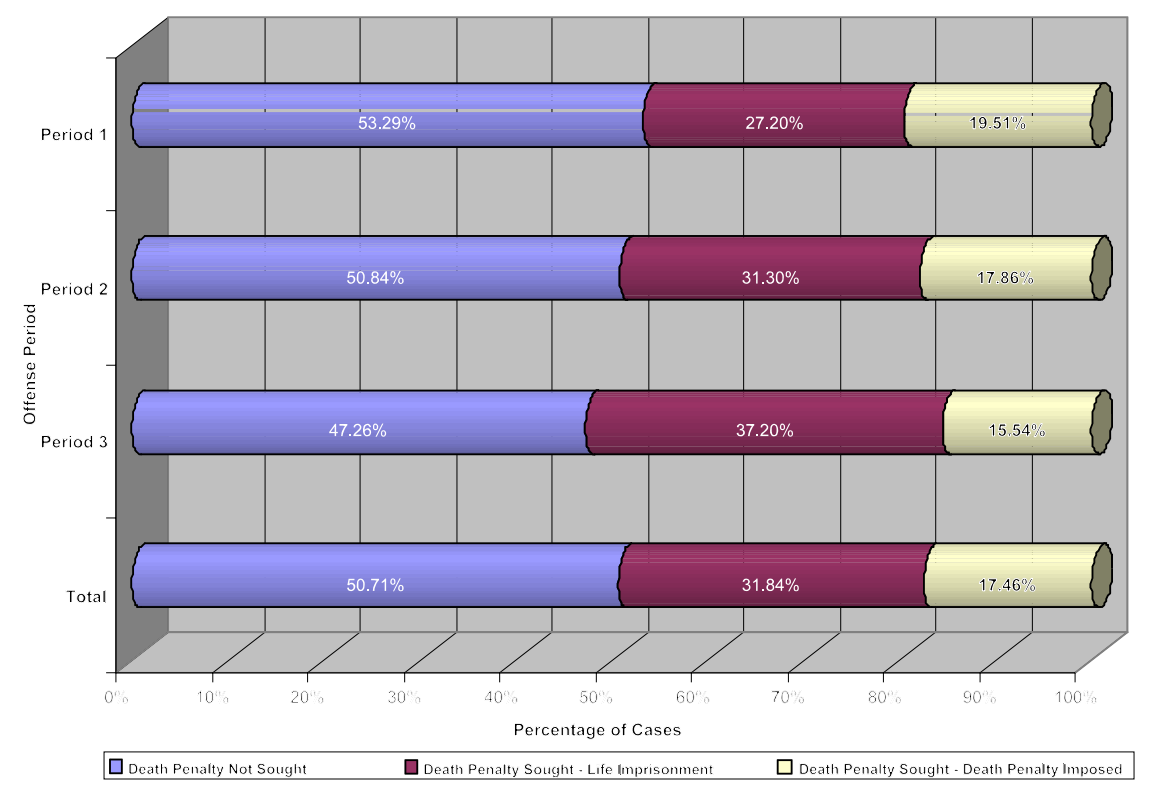

Figure 2 indicates a consistent decrease in the imposition of the death penalty by the sentencing body in Pennsylvania. In analyzing the causes of this phenomenon, we recognized that one potential factor could be the identity of the sentencing body; in other words, we questioned whether there is any difference between the trial court imposing a death sentence on a capital defendant as opposed to the jury performing that function.

Table 7 clearly shows that there is a great deviation in the sentencing patterns of the trial court and the jury. The fact that, when the Commonwealth seeks the death penalty, the jury is five times more likely to sentence to death than is the trial court is remarkable. Even taking into account the confidence intervals, the jury is still three-and-one-half times more likely $(41.80 \%$ versus $12.27 \%$ ) to sentence to death than is the trial court. This would indicate that a capital defendant, convicted of first-degree murder, would fare better before

149. We have removed from this graphical representation the twenty-seven cases for which we do not know the Offense Date Period. In nineteen of those cases, the Commonwealth did not seek the death penalty. In the other eight cases, the Commonwealth sought the death penalty, but the sentencing body did not impose capital punishment. 
the trial court than a jury during the sentencing phase. Also of note, as further expounded upon by Table 8 , the trial court conducted approximately $26 \%$ of first-degree murder sentencing hearings during the period encompassed by our study. ${ }^{150}$ Keeping in mind this disparity, however, the defendant does not have the unfettered right to seek sentencing by the trial court. ${ }^{151}$

Table 7-Sentence Imposed by Sentencing Body

\begin{tabular}{|ccccccc|}
\hline $\begin{array}{c}\text { Sentencing } \\
\text { Body }\end{array}$ & Death & Life & $\begin{array}{c}\text { Notal } \\
\text { Cases }\end{array}$ & $\begin{array}{c}\text { \% Death } \\
\text { Penalty }\end{array}$ & $\begin{array}{c}\text { Standard } \\
\text { Deviation }\end{array}$ & $\begin{array}{c}95 \% \\
\text { Confidence } \\
\text { Interval }\end{array}$ \\
\hline Jury & 392 & 477 & 869 & $\mathbf{4 5 . 1 1 \%}$ & 0.4979 & $\begin{array}{c}45.11 \% \pm \\
3.31 \%\end{array}$ \\
\hline $\begin{array}{c}\text { Trial } \\
\text { Court }\end{array}$ & 28 & 281 & 309 & $\mathbf{9 . 0 6 \%}$ & 0.2875 & $\begin{array}{c}9.06 \% \pm \\
3.21 \%\end{array}$ \\
\hline Unknown & 0 & 8 & 8 & $\mathbf{0 \%}$ & N/A & N/A \\
\hline Total & $\mathbf{4 2 0}$ & $\mathbf{7 6 6}$ & $\mathbf{1 1 8 6}$ & $\mathbf{3 5 . 4 1 \%}$ & $\mathbf{0 . 4 7 8 5}$ & $\begin{array}{c}\mathbf{3 5 . 4 1 \%} \\
\mathbf{2 . 7 2 \%}\end{array}$ \\
\hline
\end{tabular}

150. This calculation represents the number of penalty phase proceedings that occurred without a jury out of the total number of penalty phase proceedings for which we know the identity of the sentencing body. We do not have information on eight of the cases, as related in Table 7.

151. 42 PA. Cons. STAT. § 9711(b) (2003). This subsection provides as follows:

If the defendant has waived a jury trial or pleaded guilty, the sentencing proceeding shall be conducted before a jury impaneled for that purpose unless waived by the defendant with the consent of the Commonwealth, in which case the trial judge shall hear the evidence and determine the penalty in the same manner as would a jury ....

Id. (emphasis added); see also Commonwealth v. Bryant, 574 A.2d 590, 596 (Pa. 1990) (stating that "[s]ince appellant neither waived a jury trial nor pleaded guilty, the trial court had no authority to permit appellant to waive a jury for the sentencing phase of the proceedings"); $c f$. PA. CONST. art. I, § 6 (added in 1998, which is after the period of study ends) ("Trial by jury shall be as heretofore, and the right thereof remain inviolate .... Furthermore, in criminal cases the Commonwealth shall have the same right to trial by jury as does the accused."); Commonwealth v. Tharp, 754 A.2d 1251, 1253 (Pa. 2000). The Tharp court stated:

[P]roviding the Commonwealth with the right to trial by jury does not violate any constitutional right held by defendants. In fact, granting the Commonwealth such a right does nothing but ensure the defendant that, should the Commonwealth invoke this right, "the result is simply that the defendant Id.

is subject to an impartial trial by jury- the very thing that the Constitution guarantees him." 
Table 8 demonstrates that, over time, there is an increase in the percentage of cases where the trial court sits as the fact finder in lieu of a jury for capital sentencing proceedings. ${ }^{152}$ Table 8 shows that, during Offense Period 3, the trial court sat as the sentencing body approximately twice as often as did the trial court in Offense Period 1 (by percentage of cases). ${ }^{153}$ Given the finding that a jury is much more likely to sentence a capital defendant to death, as shown by Table 7 , the fact that the sentencing determinations are being handled more frequently by the trial court as time progresses might help to explain our finding in Table 6 that the sentence of death, when sought, is imposed less over time.

Table 8-Sentencing Body by Offense Period

\begin{tabular}{|ccccccc|}
\hline $\begin{array}{c}\text { Offense } \\
\text { Period }\end{array}$ & $\begin{array}{c}\text { Trial } \\
\text { Court }\end{array}$ & Jury & Total $\begin{array}{c}\text { \% Trial } \\
\text { Court }\end{array}$ & $\begin{array}{c}\text { Standard } \\
\text { Deviation }\end{array}$ & $\begin{array}{c}95 \% \\
\text { Confidence } \\
\text { Interval }\end{array}$ \\
\hline $\begin{array}{c}\text { To 9/5/86 } \\
\text { (Period } 1)\end{array}$ & 78 & 381 & 459 & $\mathbf{1 6 . 9 9 \%}$ & 0.3760 & $16.99 \% \pm 3.44 \%$ \\
\hline $\begin{array}{c}9 / 5 / 86- \\
12 / 21 / 89 \\
(\text { Period } 2)\end{array}$ & 63 & 171 & 234 & $\mathbf{2 6 . 9 2 \%}$ & 0.4445 & $26.92 \% \pm 5.70 \%$ \\
\hline $\begin{array}{c}12 / 21 / 89- \\
6 / 25 / 97\end{array}$ & 163 & 314 & 477 & $\mathbf{3 4 . 1 7 \%}$ & 0.4748 & $34.17 \% \pm 4.26 \%$ \\
$($ Period 3$)$ & & & & & & \\
\hline Total & $\mathbf{3 0 4}$ & $\mathbf{8 6 6}$ & $\mathbf{1 1 7 0}$ & $\mathbf{2 5 . 9 8 \%}$ & $\mathbf{0 . 4 3 8 7}$ & $\mathbf{2 5 . 9 8 \%} \pm \mathbf{2 . 5 1 \%}$ \\
\hline
\end{tabular}

152. Note that there are sixteen records eliminated from Table 8 - eight of the records did not indicate the date of the offense and eight of the records did not indicate the identity of the sentencing body. We have excluded these cases from the table for ease of comprehension.

153. Taking into account confidence intervals, the increase in the percentage of sentencing proceedings conducted by the trial court, as opposed to a jury, from Offense Period 1 to Offense Period 3 ranges from $46.40 \%$ to $185.72 \%$. 
Table 9-Sentencing Body by Location of the Trial (Philadelphia or Not) ${ }^{154}$

\begin{tabular}{|ccccccc|}
\hline $\begin{array}{c}\text { County of } \\
\text { Sentencing }\end{array}$ & Jury & $\begin{array}{c}\text { Trial } \\
\text { Court }\end{array}$ & Total & $\begin{array}{c}\% \\
\text { Trial } \\
\text { Court }\end{array}$ & $\begin{array}{c}\text { Standard } \\
\text { Deviation }\end{array}$ & $\begin{array}{c}95 \% \\
\text { Confidence } \\
\text { Interval }\end{array}$ \\
\hline Philadelphia & 490 & 183 & 673 & $\mathbf{2 7 . 1 9 \%}$ & 0.4453 & $27.19 \% \pm 3.36 \%$ \\
\hline Not Philadelphia & 379 & 126 & 505 & $\mathbf{2 4 . 9 5 \%}$ & 0.4332 & $24.95 \% \pm 3.78 \%$ \\
\hline Total & $\mathbf{8 6 9}$ & $\mathbf{3 0 9}$ & $\mathbf{1 1 7 8}$ & $\mathbf{2 6 . 2 3 \%}$ & $\mathbf{0 . 4 4 0 1}$ & $\begin{array}{c}\mathbf{2 6 . 2 3 \%} \pm \\
\mathbf{2 . 5 1 \%}\end{array}$ \\
\hline
\end{tabular}

Interestingly, the dichotomy in sentencing between the trial court and the jury remains consistent even when geographic and race-based factors are taken into account. Specifically, we found, as demonstrated by Table 9, that the percentage of cases presented to the trial court in Philadelphia County is similar to the percentage in the rest of the state and, as seen in Table 10, the statistics remain constant irrespective of the race of the defendant. We also found that, when the Commonwealth seeks the death penalty, the race of the defendant does not have an impact on whether or not the defendant is sentenced to die. Indeed, 250 out of 708 Black defendants, or $35.31 \%$, were sentenced to death; 140 out of 379 White defendants, or $36.94 \%$, were sentenced to death; 30 out of 99 defendants of other races, including persons of Asian and Hispanic descent, or $30.30 \%$, were sentenced to death.

In light of our interest in the interplay between the increasing number of available aggravating circumstances and the imposition of the death penalty, and given our discovery of the disparity between the rates at which the trial court and jury sentence capital defendants to death, finally, we endeavored to research whether there is any correlation between various aggravators and the identity of the sentencing body. Specifically, we wanted to ascertain if the difference in rates of the imposition of the death penalty could be explained by the nature of the cases being presented to the trial court as opposed to a jury.

154. There are eight records eliminated from consideration in Table 9 because we do not know whether the trial court or a jury determined the sentence. 
Table 10 - Sentencing Body by Race of the Defendant ${ }^{155}$

\begin{tabular}{|ccccccc|}
\hline $\begin{array}{c}\text { Race of } \\
\text { Defendant }\end{array}$ & Jury & $\begin{array}{c}\text { Trial } \\
\text { Court }\end{array}$ & Total & $\begin{array}{c}\text { \% Trial } \\
\text { Court }\end{array}$ & $\begin{array}{c}\text { Standard } \\
\text { Deviation }\end{array}$ & $\begin{array}{c}95 \% \\
\text { Confidence } \\
\text { Interval }\end{array}$ \\
\hline Black & 522 & 181 & 703 & $\mathbf{2 5 . 7 5 \%}$ & 0.4376 & $\begin{array}{c}25.75 \% \pm \\
3.23 \%\end{array}$ \\
\hline White & 279 & 98 & 377 & $\mathbf{2 5 . 9 9 \%}$ & 0.4392 & $\begin{array}{c}25.99 \% \pm \\
4.43 \%\end{array}$ \\
\hline Other & 68 & 30 & 98 & $\mathbf{3 0 . 6 1 \%}$ & 0.4633 & $\begin{array}{c}30.61 \% \pm \\
9.31 \%\end{array}$ \\
\hline Total & $\mathbf{3 0 9}$ & $\mathbf{8 6 9}$ & $\mathbf{1 1 7 8}$ & $\mathbf{2 6 . 2 3 \%}$ & $\mathbf{0 . 4 4 0 1}$ & $\begin{array}{c}\mathbf{2 6 . 2 3 \%} \pm \\
\mathbf{2 . 5 1 \%}\end{array}$ \\
\hline
\end{tabular}

To engage in this phase of our study, we first identified those aggravating circumstances whose presence led the sentencing body to impose the death penalty more frequently; we term these "super aggravators." We conceptualized the "super aggravator" as a factor, relevant in determining the sentence that, when present, makes either the case then at bar or the defendant seem so heinous that the sentencing body tends to impose the death penalty more frequently than not. We then looked at the percentage of cases where these "super aggravators" were presented to the trial court versus a jury and compared that figure to the overall percentage of cases presented to the trial court versus a jury.

155. There are eight records eliminated from consideration in Table 10 because we do not know whether the trial court or a jury determined the sentence. The terms used to identify the race of the defendant are taken directly from the first-degree murder verdict forms and the AOPC Database. 
Table 11-Percentage Death Penalty Imposed When Specific Aggravators Are Found

\begin{tabular}{|c|c|c|c|c|c|}
\hline $\begin{array}{c}\text { Aggravating Circumstances } \\
\text { Found }\end{array}$ & $\begin{array}{l}\text { Times } \\
\text { Found }\end{array}$ & $\begin{array}{l}\text { Times } \\
\text { Death }\end{array}$ & $\begin{array}{c}\% \\
\text { Death }\end{array}$ & $\begin{array}{l}\text { Standard } \\
\text { Deviation }\end{array}$ & $\begin{array}{c}95 \% \\
\text { Confidence } \\
\text { Interval }\end{array}$ \\
\hline Line of Duty & 23 & 14 & $60.87 \%$ & 0.4990 & $\begin{array}{r}60.87 \% \pm \\
21.54 \%\end{array}$ \\
\hline Murder for Hire & 41 & 21 & $51.22 \%$ & 0.5061 & $\begin{array}{r}51.22 \% \pm \\
15.96 \%\end{array}$ \\
\hline Ransom/Shield & 6 & 5 & $83.33 \%$ & 0.4082 & $\begin{array}{r}83.33 \% \pm \\
42.83 \%\end{array}$ \\
\hline Hijacking & 0 & 0 & N/A & $\mathrm{N} / \mathrm{A}$ & $\mathrm{N} / \mathrm{A}$ \\
\hline Prosecution Witness & 42 & 33 & $78.57 \%$ & 0.4153 & $\begin{array}{r}78.57 \% \pm \\
12.94 \%\end{array}$ \\
\hline Felony Murder & 355 & 219 & $61.69 \%$ & 0.4868 & $\begin{array}{r}61.69 \% \pm \\
5.08 \%\end{array}$ \\
\hline Grave Risk of Death & 176 & 89 & $50.57 \%$ & 0.5014 & $\begin{array}{r}50.57 \% \pm \\
7.41 \%\end{array}$ \\
\hline Torture & 78 & 66 & $84.62 \%$ & 0.3631 & $\begin{array}{r}84.62 \% \pm \\
8.18 \%\end{array}$ \\
\hline $\begin{array}{c}\text { Significant History of Felony } \\
\text { Convictions for Acts of } \\
\text { Violence }\end{array}$ & 164 & 134 & $81.71 \%$ & 0.3878 & $\begin{array}{r}81.71 \% \pm \\
5.94 \%\end{array}$ \\
\hline $\begin{array}{l}\text { Prior Crimes-Life in Prison } \\
\text { or Death Sentence Imposable }\end{array}$ & 96 & 83 & $86.46 \%$ & 0.3440 & $\begin{array}{r}86.46 \% \pm \\
6.99 \%\end{array}$ \\
\hline Prior Murder & 154 & 108 & $70.13 \%$ & 0.4592 & $\begin{array}{r}70.13 \% \pm \\
7.25 \%\end{array}$ \\
\hline $\begin{array}{l}\text { Prior Voluntary } \\
\text { Manslaughter }\end{array}$ & 9 & 6 & $66.67 \%$ & 0.5000 & $\begin{array}{r}66.67 \% \pm \\
38.50 \%\end{array}$ \\
\hline
\end{tabular}




\begin{tabular}{|cccccr|}
\hline $\begin{array}{c}\text { Aggravating Circumstances } \\
\text { Found }\end{array}$ & $\begin{array}{c}\text { Times } \\
\text { Found }\end{array}$ & $\begin{array}{c}\text { Times } \\
\text { Death }\end{array}$ & $\begin{array}{c}\% \\
\text { Death }\end{array}$ & $\begin{array}{r}\text { Standard } \\
\text { Deviation }\end{array}$ & $\begin{array}{r}95 \% \\
\text { Confidence } \\
\text { Interval }\end{array}$ \\
\hline Drug Felony & 5 & 2 & $\mathbf{4 0 . 0 0 \%}$ & 0.5477 & $\begin{array}{r}40.00 \% \pm \\
68.10 \%\end{array}$ \\
\hline Drug Dealing Aggravator & 19 & 7 & $\mathbf{3 6 . 8 4 \%}$ & 0.4956 & $\begin{array}{r}36.84 \% \pm \\
23.88 \%\end{array}$ \\
\hline Non-Governmental Informant & 6 & 1 & $\mathbf{1 6 . 6 7 \%}$ & 0.4082 & $\begin{array}{r}16.67 \% \pm \\
42.83 \%\end{array}$ \\
\hline Victim Under 12 & 20 & 15 & $\mathbf{7 5 . 0 0 \%}$ & 0.4443 & $75.00 \% \pm$ \\
& & & & & $20.76 \%$ \\
\hline
\end{tabular}

We statistically define "super aggravators" as any aggravating circumstance, when found, where, taking into account the $95 \%$ confidence interval, the sentencing body sentences the defendant to death at least $60 \%$ of the time. Table 11 lays out the frequency at which sentences of death are imposed when the sentencing body finds each aggravating circumstance. Utilizing our statistical definition of "super aggravators," the following would classify: (1) the victim was a prosecution witness to a crime committed by the defendant and was killed to prevent his or her testimony; ${ }^{156}(2)$ torture; ${ }^{157}$ (3) significant history of felony convictions for acts of violence; ${ }^{158}$ (4) prior convictions for which sentences of life imprisonment or death were imposable; ${ }^{159}$ and (5) prior murder convictions. ${ }^{160}$ 
Table 11A - Percentage Death Penalty Imposed When Only One Aggravator Is Found

\begin{tabular}{|c|c|c|c|}
\hline Aggravator Found & $\begin{array}{l}\text { Times } \\
\text { Found }\end{array}$ & $\begin{array}{l}\text { Times } \\
\text { Death }\end{array}$ & $\begin{array}{c}\text { Percentage } \\
\text { Death }\end{array}$ \\
\hline Line of Duty & 4 & 2 & $50.00 \%$ \\
\hline Murder for Hire & 15 & 6 & $40.00 \%$ \\
\hline Ransom/Shield & 1 & 0 & $0.00 \%$ \\
\hline Hijacking & 0 & 0 & N/A \\
\hline Prosecution Witness & 8 & 5 & $62.50 \%$ \\
\hline Felony Murder & 134 & 51 & $38.06 \%$ \\
\hline Grave Risk of Death & 61 & 13 & $21.31 \%$ \\
\hline Torture & 12 & 6 & $\mathbf{5 0 . 0 0 \%}$ \\
\hline $\begin{array}{c}\text { Significant History of Felony } \\
\text { Convictions for Acts of } \\
\text { Violence }\end{array}$ & 32 & 22 & $68.75 \%$ \\
\hline $\begin{array}{l}\text { Prior Crimes-Life in Prison } \\
\text { or Death Sentence Imposable }\end{array}$ & 27 & 20 & $74.07 \%$ \\
\hline Prior Murder & 40 & 27 & $67.50 \%$ \\
\hline Prior Voluntary Manslaughter & 3 & 2 & $66.67 \%$ \\
\hline Drug Felony & 1 & 0 & $0.00 \%$ \\
\hline Drug Dealing Aggravator & 8 & 2 & $25.00 \%$ \\
\hline Non-Governmental Informant & 6 & 1 & $16.67 \%$ \\
\hline Victim Under 12 & 6 & 1 & $16.67 \%$ \\
\hline
\end{tabular}


There were 358 cases where the sentencing body found the existence of exactly one aggravating circumstance. The frequency and percentage of those cases resulting in a death sentence are as follows:

Table 12-Aggravators Presented to the Trial Court

\begin{tabular}{|c|c|c|c|c|c|}
\hline $\begin{array}{l}\text { Aggravators Presented } \\
\text { to Trial Court }\end{array}$ & $\begin{array}{c}\text { Times } \\
\text { Presented }\end{array}$ & $\begin{array}{l}\text { Times } \\
\text { Found }\end{array}$ & $\begin{array}{l}\text { Times } \\
\text { Death }\end{array}$ & $\begin{array}{l}\% \text { Found } \\
\text { When } \\
\text { Presented }\end{array}$ & $\begin{array}{l}\% \text { Death } \\
\text { When } \\
\text { Found }\end{array}$ \\
\hline Prosecution Witness & 21 & 3 & 3 & $14.29 \%$ & $100.00 \%$ \\
\hline Torture & 28 & 3 & 0 & $10.71 \%$ & $0.00 \%$ \\
\hline $\begin{array}{l}\text { Significant History } \\
\text { of Felony } \\
\text { Convictions for Acts } \\
\text { of Violence }\end{array}$ & 72 & 15 & 3 & $20.83 \%$ & $20.00 \%$ \\
\hline $\begin{array}{l}\text { Prior Crime_Life in } \\
\text { Prison or Death } \\
\text { Sentence Imposable }\end{array}$ & 36 & 12 & 10 & $33.33 \%$ & $83.33 \%$ \\
\hline Prior Murder & 73 & 27 & 14 & $36.99 \%$ & $51.85 \%$ \\
\hline $\begin{array}{l}\text { Total-Super } \\
\text { Aggravators }\end{array}$ & 230 & 60 & 30 & $26.09 \%$ & $50.00 \%$ \\
\hline $\begin{array}{c}\text { All Other } \\
\text { Aggravators }\end{array}$ & 336 & 85 & 20 & $25.30 \%$ & $23.53 \%$ \\
\hline Total & 566 & 145 & 50 & $25.62 \%$ & $34.48 \%$ \\
\hline
\end{tabular}

The preceding table is consistent with our findings in Table 11 regarding which aggravators, when found, are more likely to lead to the imposition of the death penalty. We note that this table indicates two additional aggravating factors (line of duty and prior voluntary manslaughter) which seem to lead to imposition of the death penalty in at least half of the cases in which they are presented singularly. We cannot, however, glean any true meaning from these statistics because the number of cases in which they were found (4 and 3, 
respectively) is too small of a dataset to have any statistical significance. Note that the "super aggravators" are bolded in this table.

We then examined whether the Commonwealth presents these "super aggravators" to juries or the trial court more often than the other aggravating circumstances. ${ }^{161}$ If that were the case, it would indicate that some of the disparity between the trial court imposing a death sentence and a jury imposing a death sentence could be explained by the nature of the case. Specifically, if juries see a greater proportion of "super aggravators" than trial courts, juries are determining the sentences in the more heinous cases.

Given that Table 11 identifies the "super aggravators," Tables 12 and 13 set forth statistics concerning any existing disparity between the nature of cases (relevant to aggravating factors) introduced before the trial court as opposed to a jury. What is of immediate note and importance is that 230 out of 955 "super aggravators" are presented to the trial court; ${ }^{162}$ this represents $24.08 \%$ of all "super aggravators." Likewise, the Commonwealth presented 336 out of 1301 of the other aggravators to the trial court, which represents $25.83 \% .{ }^{163}$ As Table 8 shows that the trial court decides on the sentence in $25.98 \%$ of cases, this clearly indicates that there is little or no disparity between the nature of cases that the Commonwealth presents to the trial court and the cases presented to a jury for the purposes of sentencing capital defendants. Specifically, assuming that there is no difference between the trial court and the jury, we would expect that the Commonwealth would present to the trial court $25.98 \%$ of all super aggravators and $25.98 \%$ of all other aggravators. Therefore, as it relates to our analytical framework of "super aggravators," the trial court and juries consider cases of similar nature on the average.

161. To examine when aggravating circumstances are found in this vein is problematic because the sentencing body determines whether the aggravator exists and whether the sentence should be set at life imprisonment or death. Because we have also demonstrated that there is a disparity in the functioning of the trial court and juries in setting the sentence, the differences between the rates at which certain aggravators are found when presented to the varying sentencing bodies do not have statistical significance.

162. The 955 number represents the aggregate of the 230 "super aggravators" presented to the trial court, as reflected in Table 12, and the 725 "super aggravators" presented to a jury, as reflected in Table 13.

163. The 1301 number represents the aggregate of the 336 other aggravators (non-super aggravators) presented to the trial court, as reflected in Table 12, and the 965 other aggravators presented to a jury, as reflected in Table 13. 
Table 13 - Aggravators Presented to a Jury

\begin{tabular}{|c|c|c|c|c|c|}
\hline $\begin{array}{l}\text { Aggravators Presented } \\
\text { to Jury }\end{array}$ & $\begin{array}{c}\text { Times } \\
\text { Presented }\end{array}$ & $\begin{array}{l}\text { Times } \\
\text { Found }\end{array}$ & $\begin{array}{l}\text { Times } \\
\text { Death }\end{array}$ & $\begin{array}{l}\% \text { Found } \\
\text { When } \\
\text { Presented }\end{array}$ & $\begin{array}{l}\text { \% Death } \\
\text { When } \\
\text { Found }\end{array}$ \\
\hline Prosecution Witness & 65 & 39 & 30 & $60.00 \%$ & $76.92 \%$ \\
\hline Torture & 155 & 75 & 66 & $48.39 \%$ & $88.00 \%$ \\
\hline $\begin{array}{l}\text { Significant History } \\
\text { of Felony } \\
\text { Convictions for Acts } \\
\text { of Violence }\end{array}$ & 257 & 149 & 131 & $57.98 \%$ & $87.92 \%$ \\
\hline $\begin{array}{l}\text { Prior Crime-Life in } \\
\text { Prison or Death } \\
\text { Sentence Imposable }\end{array}$ & 111 & 84 & 73 & $75.68 \%$ & $86.90 \%$ \\
\hline Prior Murder & 137 & 125 & 94 & $91.24 \%$ & $75.20 \%$ \\
\hline $\begin{array}{l}\text { Total—Super } \\
\text { Aggravators }\end{array}$ & 725 & 472 & 394 & $65.10 \%$ & $83.47 \%$ \\
\hline $\begin{array}{c}\text { All Other } \\
\text { Aggravators }\end{array}$ & 965 & 572 & 359 & $59.27 \%$ & $62.76 \%$ \\
\hline Total & 1690 & 1044 & 753 & $61.78 \%$ & $72.13 \%$ \\
\hline
\end{tabular}

The comparison between Tables 12 and 13 also reveals other interesting trends. A trial court finds the existence of aggravating circumstances presented to it approximately $25.62 \%$ of the time, and this number remains relatively stable irrespective of whether the aggravating circumstance is a "super aggravator." On the same note, juries find $61.78 \%$ of the aggravating circumstances presented by the Commonwealth; while juries are more likely to find the existence of "super aggravators" when presented $(65.10 \%$ versus $59.27 \%$ ), this disparity is significantly more narrow than the disparity between "super aggravators" and other aggravators leading to imposition of the death penalty when found $(83.47 \%$ versus $62.76 \%)$. 
Given our observations, it is evident that although presented with cases of a similar nature, the trial court and juries sentence capital defendants to death at disparate rates. Therefore, the difference in the nature of the cases presented to the varying sentencing bodies does not explain the vast discrepancy found in Table 7 relating to the percentage of cases in which the trial court or a jury imposes a death sentence. While the bare statistics cannot explain this trial court-jury dichotomy, it is entirely possible that its foundation is built in some social phenomenon. Conceivably, a jury is comprised of twelve individuals who remain relatively anonymous and must all agree on a verdict; the trial court, on the other hand, is a single person who affixes his or her name to the sentencing verdict and remains associated with that sentence throughout his or her life.

\section{CONCLUSION}

In conclusion, the statistics do not bear out the concern, as articulated by members of the legislature and evidenced in the hourglass-like shape of the historical changes to the death penalty scheme, that the increase in the number of aggravating circumstances available, without a concomitant increase in the number of mitigating circumstances available, strips the sentencing body of any discretion in setting the penalty for a first-degree murder conviction. Therefore, there is no basis for the fear that the amendments to the death penalty statute make the imposition of the death penalty more mandatory. In fact, while the Commonwealth has increased the number of cases where it seeks the death penalty as the number of aggravators available has increased, the sentencing body is less likely to impose the death penalty in those cases and, in fact, over all first-degree murder convictions, the death penalty is being imposed at a lower rate, irrespective of whether the Commonwealth seeks the death penalty. Our research does indicate that the identity of the sentencing body (be it trial court or jury) has an obvious and marked impact on whether or not the defendant will be sentenced to death. This disparity cannot be explained by assuming that the trial court hears different cases from those considered by juries. Based on our analysis, the opposite is true - the cases heard by the varying sentencing bodies are the same, but the result unquestionably differs. 